\title{
AS LICENCIATURAS EM HISTÓRIA E A LEI 10.639/03 - PERCURSOS DE FORMAC̦ÃO PARA O TRATO COM A DIFERENC̣A?
}

\author{
MAURO CEZAR COELHO ${ }^{*}$ \\ ORCID: https://orcid.org/0000-0003-3635-4348 \\ WILMA DE NAZARÉ BAÍA COELHO ${ }^{1 * *}$ \\ ORCID: https://orcid.org/0000-0001-8679-809X
}

RESUMO: $\mathrm{O}$ artigo aborda a formação do professor de História, ao longo dos últimos quinze anos, considerando a legislação que reformula a perspectiva de História do Brasil nos currículos da Educação Básica. As diretrizes nacionais para a educação para as relações étnico-raciais, acarretam mudanças nos percursos de formação, as quais projetam alterações substantivas no modelo usualmente adotado para a formação docente em História. Diante disso, o artigo analisa o impacto de tais alterações, a partir dos trajetos curriculares de cursos oferecidos por universidades federais em dez unidades da federação. A partir da consideração de tais trajetos, pretende-se analisar o espaço destinado à formação para as relações étnico-raciais e para o trato com a diferença. Argumentamos que as lacunas existentes em relação à implementação da lei são devedoras do modo pelo qual a formação de professores é concebida e assumida nos percursos curriculares estudados. Palavras-chave: Formação de professores; Ensino de História; Lei 10.639/03; Currículo.

THE DEGREE IN HISTORY TEACHING AND THE 10.639/03 STATUTE - TRAINING PATHS TO DEAL WITH DIFFERENCE?

ABSTRACT: The article deals with the formation of History teachers over the last fifteen years, considering the legislation that reformulates the perspective of Brazilian History in Basic Education's curricula. National guidelines for education in ethnic-racial relations bring about changes in the training

\footnotetext{
${ }^{1}$ Universidade Federal do Pará, Belém, PA, Brasil

"Doutor em História pela Universidade de São Paulo, Professor Associado da Universidade Federal do Pará. GERA (Núcleo de Estudos e Pesquisas sobre Formação de Professores e Relações Étnico-Raciais) IOFICINAS DE HISTÓRIA (Grupo de Pesquisas Oficinas de História) IGPHÍNDIA (Grupo de Pesquisas de História Indígena e do Indigenismo na Amazônia). E-mail:<mauroccoelho@yahoo.com.br > .

" Doutora em Educação pela Universidade Federal do Rio Grande do Norte, Professora Associada da Universidade Federal do Pará. GERA (Núcleo de Estudos e Pesquisas sobre Formação de Professores e Relações Étnico-Raciais). Bolsista Produtividade do CNPq. E-mail:<wilmacoelho@yahoo.com.br > .
} 
paths, which develops substantive changes in the model usually adopted for teacher formation in History. Therefore, the article analyzes the impact of such changes, parting from the curricular paths of courses offered by federal universities in ten units of the federation. From the consideration of such trajectories, we intend to analyze the space destined for ethnic-racial relations formation and to deal with difference. We argue that the existing gaps related to the implementation of the basic statute are due to the way in which teacher formation is conceived and assumed in the curriculum paths studied.

Keywords: Teacher training; History teaching; Law 10.639/03; Curriculum.

\section{INTRODUCุÃO}

Passados quinze anos da promulgação da Lei n ${ }^{\circ} 10.639 / 2003,{ }^{1}$ continuamos às voltas com os desafios que sua implementação impõe. Os fóruns de discussão, reunindo pesquisadores e militantes de movimentos sociais, reclamam da leniência do poder público, especialmente das secretarias de educação, em garantir a inclusão das temáticas referidas naquele instrumento jurídico na Educação ofertada pelos sistemas educacionais. Essas são demandas importantes. Todavia, elas não esgotam a questão.

Resultado de uma conquista dos movimentos sociais - com destaque para o Movimento Negro - a legislação em discussão não tem como finalidade última a inclusão de conteúdos. Não que tal inclusão não seja importante, bem entendido. Como parte de uma política de ação afirmativa, ${ }^{2}$ informada por uma postura crítica em relação à memória histórica e comprometida com a luta pela erradicação do racismo, a Lei no 10.639/2003 assume os conteúdos de História da África e da Cultura Afro-brasileira como meios a partir dos quais se pretende proceder à crítica da memória. Considerar, então, a implementação da lei significa verificar em que medida os sistemas educacionais concorrem para aquela crítica - na qual a luta contra a discriminação e o preconceito sejam a tônica.

Diante disso, o presente artigo busca analisar como os percursos de formação de professores de História em dez universidades federais incorporam os princípios legais supracitados. Nossa intenção é dimensionar a medida pela qual aqueles cursos abordam os pressupostos daquela legislação e, em particular, as Diretrizes para a Educação para as Relações Étnico-Raciais. Argumentamos que as lacunas existentes em relação à implementação da lei são devedoras do modo pelo qual a formação de professores é concebida e assumida nos percursos curriculares estudados. 


\section{EDUCAÇÃO PARA AS RELAC̣̃̃ES ÉTNICO-RACIAIS}

A Lei no $10.639 / 2003$ tem sido objeto de um sem número de estudos. Uma grande parte deles se ocupa com os processos de aplicação da lei, buscando dar conta de como as instituições de Educação Básica, particularmente, vêm enfrentando os desafios colocados pela legislação, sobretudo, o tratamento dos temas por ela introduzidos: a História da África e da Cultura Afro-brasileira. Uma parte significativa destes trabalhos aponta que, nas escolas, os objetivos da legislação são sumariamente abordados em efemérides como a Semana da Consciência Negra, quando aspectos assumidos como constituintes da cultura afro-brasileira são expostos e tematizados. ${ }^{3}$

Estudiosos do tema têm apontado os desdobramentos de tais abordagens. Ao limitarem o trato com a História da África e com a Cultura Afro-brasileira a episódios que fogem da rotina escolar, sem o estabelecimento de relações efetivas com o saber cotidianamente trabalhado em sala de aula, acaba-se por referendar aquilo que se pretendia combater. As abordagens festivas, por meio das quais aspectos isolados da cultura afro-brasileira, especialmente, são assumidos como índices de uma cultura particular, com relação fortuita com as culturas dos alunos e, principalmente, com aquelas que são abordadas pelo conteúdo escolar acentuam o caráter incidental, secundário e subordinado da História da África e da Cultura Afro-brasileira. ${ }^{4}$ Para Ana Canen, o que se verifica em posturas como essas é a transformação de índices de cultura em aspectos folclóricos e curiosos. ${ }^{5}$

Esse quadro está, em larga medida, relacionado às formas pelas quais a legislação é percebida. Em grande parte dos casos, a perspectiva assumida considera que a política na qual a legislação está inserida compreende, apenas, a inclusão de alguns conteúdos. Isso pode ser notado tanto no que tange às temáticas africanas e afrobrasileiras quanto no que se refere à história dos povos indígenas. Nos dois casos, o que se tem constatado ao longo dos últimos anos é um acrescentamento de conteúdos ao currículo da Educação Básica. Tome-se como exemplo a literatura didática.

Os livros didáticos conformam um dos índices do que deve ser ensinado nas Escolas brasileiras. Em primeiro lugar, porque é um recurso universal. Além do fato de ser distribuído gratuitamente em todas as escolas públicas brasileiras, ele constitui um recurso que abarca diversos suportes discursivos - textos didáticos, excertos de obras (acadêmicas, literárias, jornalísticas etc.), ilustrações, reproduções de imagens, mapas, avaliações etc. Essa sua condição o torna um suporte valioso nas mãos de professores e alunos. Ademais, o fato de ser objeto de uma avaliação 
rigorosa, por parte de uma equipe de pesquisadores qualificados, torna $\mathrm{o}$ livro didático um elemento importante da cultura escolar. Ele, conforme apontam os editais do PNLD, ${ }^{6}$ deve reunir o conhecimento atualizado e pertinente que deve ser operado pelas escolas. ${ }^{7}$

Pois, o que as pesquisas acerca das temáticas abarcadas pela legislação em destaque apontam é que, desde o ano de 2003, os livros didáticos têm aumentado o espaço destinado à História da África, à Cultura Afro-brasileira e à História dos Povos Indígenas. Isto não tem significado, no entanto, uma alteração nas perspectivas acerca da História do Brasil presentes naquelas obras. Os africanos, os negros e indígenas permanecem como personagens subalternos, coadjuvantes e a África e a América antes da conquista são percebidos como espaços sem história. Continua soberana a perspectiva eurocêntrica, segundo a qual a História confunde-se com a trajetória europeia, a qual intervém e significa a trajetória brasileira. ${ }^{8}$

O escopo da legislação que altera o artigo 26 da Lei de Diretrizes e Bases da Educação demanda algo muito diverso. Essa legislação e a política da qual faz parte congregam um esforço promovido pela sociedade civil organizada, no qual atuaram ativa, efetiva e destacadamente movimentos negros e indígenas, em luta contra as diversas formas de discriminação que os atingiam inclusive aquelas relativas à conformação da memória. ${ }^{9}$ Foi essa a postura assumida pela legislação ao regular a implementação da Lei $\mathrm{n}^{\mathrm{o}} 10.639 / 2003$, por meio das Diretrizes Curriculares Nacionais para a Educação das Relações Étnico-Raciais.

O parecer aprovado pelo Conselho Nacional de Educação aponta que a inclusão de conteúdos não é o objetivo final da legislação. A trajetória histórica dos povos aludidos pela lei serviria, antes, à "divulgação e produção de conhecimentos, bem como de atitudes, posturas e valores que eduquem os cidadãos quanto à pluralidade étnico-racial". ${ }^{10} \mathrm{O}$ fim último da política educacional, portanto, é inclusão de temas e princípios contrários às perspectivas demarcadas e informadas pelo racismo. Ora, está claro que a memória histórica brasileira é informada por um viés racista, especialmente demonstrado no "mito da democracia racial" - fábula sobre a nossa formação, segundo a qual os três elementos formadores ocuparam papéis e funções distintas, correspondentes ao valor de suas raças. Assim, conforme o "mito", ao branco coube os atributos estruturantes da civilização - especialmente a herança europeia - e aos demais os caracteres secundários da nossa formação, quando não a responsabilidade por boa parte de nossos vícios. ${ }^{11}$

As Diretrizes Curriculares Nacionais para a Educação das Relações Étnico-Raciais opõem-se, justamente, à perspectiva 
consolidada por nossa memória histórica e aos desdobramentos que o "mito da democracia racial" (mas, não apenas ele) carregam. Não por outra razão, elas relacionam a efetivação da legislação ao "respeito aos direitos legais e valorização de identidade, na busca da consolidação da democracia brasileira". ${ }^{12}$ Para tanto, evidentemente, não é suficiente a mera inclusão de conteúdos. Antes, é preciso que tais conteúdos sejam inseridos em um contexto de discussão da matriz que tem informado a memória histórica e alimentado um ideário de fundo racista que ampara e legitima preconceitos e discriminações.

Nesse sentido, a reformulação do artigo 26 da Lei de Diretrizes e Bases da Educação demanda a adoção de uma outra perspectiva nas abordagens da História do Brasil e, consequentemente, nos processos de formação docente. Elas reclamam a assunção da luta contra o racismo e seus desdobramentos como uma dimensão relevante dos processos de formação docente, por meio da discussão e do debate não apenas da crítica à memória, mas das posturas profissionais necessárias ao professor para promover uma educação antirracista. ${ }^{13}$

Em que pese a responsabilidade das secretarias de educação e das escolas na oferta de formação continuada aos docentes, ${ }^{14}$ não se pode desconsiderar a responsabilidade dos cursos de licenciatura ${ }^{15}$ no esforço pela implementação daquela legislação. Encarregados exclusivos pela oferta de profissionais para a Educação Básica, os cursos de formação de professores das instituições de ensino superior desempenham um papel fundamental na efetivação dos princípios presentes nas diretrizes a que nos referimos. Em primeiro lugar, porque neles os egressos dos cursos de licenciatura têm acesso às discussões consideradas fundamentais para a sua atuação profissional, participando, assim, do que se pode chamar de Sistema Nacional de Educação. ${ }^{16}$ Em segundo lugar, porque os professores são os responsáveis pelo engendramento dos processos de ensinoaprendizagem, por meio dos quais crianças, adolescentes e adultos inseridos na Educação Básica têm acesso ao mundo do conhecimento formal e aos princípios e valores definidos pela legislação. ${ }^{17}$

Formar docentes capazes de concretizar as diretrizes em processos de ensino-aprendizagem que promovam uma educação baseada no respeito à diferença, à pluralidade étnico-racial e voltada para a valorização das diversas identidades é não apenas uma demanda legal, mas um compromisso cívico. Diante disso, consideramos pertinente analisar como cursos de licenciatura em história têm se posicionado diante das diretrizes e encaminhado a formação de professores comprometidos com os valores estabelecidos pela legislação educacional. 


\section{O UNIVERSO ESTUDADO - LICENCIATURAS EM HISTÓRIA}

Para dar conta de nosso objetivo, selecionamos dez projetos políticos pedagógicos de universidades brasileiras. Para os fins deste artigo, consideramos analisar projetos de formação em todas as regiões do país, a razão de dois projetos em cada região. Optamos por trabalhar com os cursos oferecidos pelas universidades federais situadas nos estados da União. Nelas, destacamos aquelas identificadas com os Estados, de modo a analisarmos os cursos que, frequentemente, assumem uma posição de referência em relação às demais instituições de ensino superior de cada Estado.

As instituições foram escolhidas em função de um critério fortuito - ter o projeto político pedagógico disponibilizado na rede mundial de computadores. Selecionamos, então, os projetos dos cursos de formação ofertado pelas universidades federais do Amapá (UNIFAP), ${ }^{18}$ Ceará (UFC), ${ }^{19}$ Goiás (UFG), ${ }^{20}$ Mato Grosso (UFMT), ${ }^{21}$ Minas Gerais (UFMG), ${ }^{22}$ Paraná (UFPR), ${ }^{23}$ Piauí (UFPI), ${ }^{24}$ Rio de Janeiro (UFRJ), ${ }^{25}$ Roraima (UFRR) ${ }^{26}$ e Santa Catarina (UFSC) ${ }^{27}$ Esse conjunto mostrouse diversificado e permitiu a formação de um quadro que consideramos representativo da oferta de cursos de licenciatura em História no país - especialmente nas universidades federais. Segundo consulta no sítio e-Mec, há 63 universidades federais no país, assim distribuídas:

TABELA I

\begin{tabular}{|l|c|l|c|}
\hline \multicolumn{5}{|c|}{ UNIVERSIDADES FEDERAIS } \\
\hline \multicolumn{1}{|c|}{ Ente federativo } & Unidade & \multicolumn{1}{c|}{ Ente federativo } & Unidade \\
\hline Acre & 1 & Paraíba & 2 \\
\hline Alagoas & 1 & Pernambuco & 3 \\
\hline Amapá & 1 & Piauí & 1 \\
\hline Amazonas & 1 & Paraná & 3 \\
\hline Bahia & 4 & Rio de Janeiro & 4 \\
\hline Ceará & 3 & Rio Grande do Norte & 2 \\
\hline Distrito Federal & 1 & Rondônia & 1 \\
\hline Espírito Santo & 1 & Roraima & 1 \\
\hline Goiás & 1 & Rio Grande do Sul & 6 \\
\hline Maranhão & 1 & Santa Catarina & 2 \\
\hline Minas Gerais & 11 & Sergipe & 1 \\
\hline Mato Grosso & 1 & São Paulo & 3 \\
\hline Mato Grosso do Sul & 2 & Tocantins & 1 \\
\hline Pará & 4 & & 63 \\
\hline
\end{tabular}

Fonte: Cadastro e-MEC de Instituições e Cursos de Educação Superior. Disponível em: http://emec.mec.gov.br. Acesso em: 27 dez. 2017. 
Consideramos, então, que o conjunto de instituições selecionadas representam o total de instituições existentes, pois, ele não apenas corresponde à 15,87\% do total de instituições, mas em todas as unidades da federação há uma universidade federal que é atribuída, justamente, àquela unidade na qual se encontra.

Os cursos cujos projetos analisamos aqui tiveram início em momentos distintos (UNIFAP, 1991; UFC, 1972; UFG, 1965; UFMT, 1979; UFMG, 1939; UFPR, 1938; UFPI, 1968; UFRJ, 1939; UFRR, 1990; UFSC, 1960). ${ }^{28}$ As datas indicam mais que o tempo de existência dos cursos, elas informam sobre a evolução da oferta de formação docente em história nas diversas regiões do país. As instituições mais antigas estão situadas no Sudeste, enquanto que as mais jovens se encontram na Região Norte nos estados que, até a década de 1980, conformavam os territórios da União. Os cursos mais antigos acionam uma experiência de várias décadas na produção de conhecimento histórico e na formação de quadros, constituindose em instituições de referência. Analisar tais cursos em conjunto permite entender como uma ou mais concepções de formação se consolidam em instituições diferentes não apenas pela sua localização no território, mas pela experiência e reflexão que acumulam.

Os Projetos Político-Pedagógicos constituíram-se, assim, em fontes fundamentais para o presente trabalho. Consideramo-los como um documento que expressa tanto o modo como a legislação educacional é praticada quanto o arbítrio do corpo docente dos cursos. ${ }^{29}$ Em relação a este último aspecto, os projetos permitem atentar para as concepções de formação compartilhadas. Assumimos os projetos como documentos que expressam discursos sobre a formação docente, os quais foram analisados a partir da técnica de análise de conteúdos, ${ }^{30}$ a fim de situar os sentidos presentes nos projetos.

Dos dez projetos de cursos analisados, sete são licenciaturas (UNIFAP, UFC, UFG, UFMT, UFMG e UFPI) e três oferecem formação conjugada (UFPR, UFRJ e UFSC), articulando bacharelado e licenciatura. As duas modalidades de formação, no entanto, não se diferenciam. A considerar os percursos curriculares expressos nos projetos políticos pedagógicos estudados, há uniformidade na formação de historiadores, independentemente da modalidade ofertada. Em todos os cursos há um conjunto de disciplinas de natureza historiográfica, voltado para a compreensão dos períodos históricos, ordenados segundo a periodização quadripartite constituída no século XIX e acrescida de estudos voltados para a compreensão da trajetória histórica do Brasil, da América e da 
região. Assim, disciplinas como História Antiga, História Medieval, História Moderna, História Contemporânea, História da América e História do Brasil estão presentes em todos os percursos analisados. Disciplinas voltadas para a reflexão sobre a História Local não estão presentes apenas nos cursos oferecidos pelos cursos da instituição de Minas Gerais e da do Rio de Janeiro.

A uniformidade dos desenhos curriculares remete para uma compreensão comum do que significa formar professores de história. Em primeiro lugar, um conhecimento aprofundado do saber de referência - da História - de como ele é produzido e acumulado. Isso é o que sugere a consideração da distribuição de carga horária somada dos diferentes percursos curriculares. Senão vejamos:

\section{GRÁFICO I. Média do Volume de Disciplinas do Percurso Curricular}

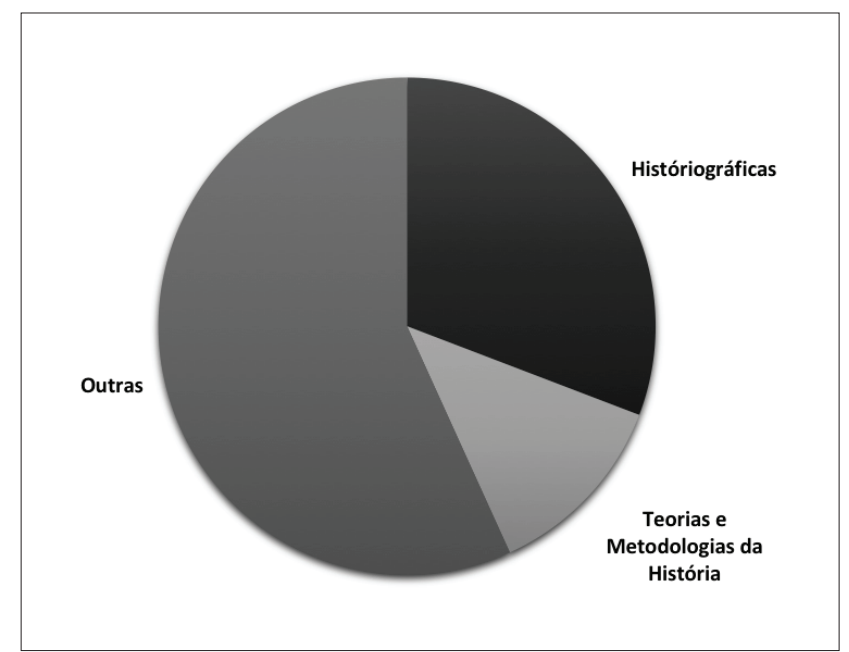

Fonte: Elaboração dos autores com base nos Projetos Político-Pedagógicos de Curso, fev.2018.

Conforme aponta o gráfico, as disciplinas que se ocupam com a produção de conhecimento histórico e com a produção historiográfica acumulada representam mais de $40 \%$ da carga horária somada de todos cursos analisados. Isso é resultado da preocupação com o domínio da produção historiográfica, expresso nos perfis de egressos presentes nos diversos Projetos Político-Pedagógicos.

Dos dez cursos analisados, apenas um deles não traz o item Perfil do Egresso. ${ }^{31}$ Nos ocuparemos dos perfis adiante, nesse momento, no entanto, é nossa intenção apenas ressaltar como o domínio da produção historiográfica e dos processos de produção de conhecimento histórico ocupam a centralidade dos percursos de formação, independentemente da modalidade ofertada 
- se bacharelado ou licenciatura. Acompanhar e participar do "debate historiográfico contemporâneo", 32 aprender as "diversas interpretações propostas pelas principais escolas historiográficas", 33 "conhecer as informações básicas referentes às diferentes épocas históricas", 34 "conhecer as vertentes teóricas que orientam as análises históricas", ${ }^{35}$ "conhecer os conteúdos referentes às diferentes épocas históricas" 36 e "desenvolver conhecimento de interpretações e tendências historiográficas" 37 são algumas das competências e habilidades valorizadas pelos cursos de formação.

Isto se deve, em larga medida à apropriação que os cursos em discussão fazem das Diretrizes Curriculares Nacionais para os Cursos de História. ${ }^{38}$ Elas estão citadas em seis Projetos PolíticoPedagógicos de curso. ${ }^{39}$ Aquelas diretrizes ressaltam a importância do domínio da produção historiográfica, ao definirem três grandes grupos de conteúdos:

Conteúdos histórico/historiográficos e práticas de pesquisa que, sob diferentes matizes e concepções teórico-metodológicas, definem e problematizam os grandes recortes espaço temporais.

Conteúdos que permitam tratamento especializado e maior verticalidade na abordagem dos temas, resguardadas as especificidades de cada instituição e dos profissionais que nelas atuam. As instituições devem assegurar que o graduando possa realizar atividades acadêmicas optativas em áreas correlatas de modo a consolidar a interlocução com outras áreas de conhecimento.

Conteúdos complementares que forneçam instrumentação mínima, permitindo a diferenciação de profissionais da área, tais como: atividades pedagógicas, fundamentos de arquivologia, de museologia, gerenciamento de patrimônio histórico, necessariamente acompanhadas de estágio. ${ }^{40}$

Conteúdos histórico/historiográficos e conteúdos que permitam diálogo com outras áreas do conhecimento assumem, naquelas diretrizes função estrutural, enquanto outros são considerados complementares - dentre os quais, aqueles relativos às atividades pedagógicas. Essa perspectiva está presente, em maior ou menor grau, em todos os Projetos Político-Pedagógicos analisados, de modo que o universo estudado - a despeito das especificidades que demarcam as duas modalidades e das particularidades regionais - compõem um quadro representativo da formação de professores de história ofertada no país.

\section{QUE FORMAÇÃO E QUAIS PROFESSORES?}

Os estudos sobre a inserção dos pressupostos da legislação supracitada nos percursos curriculares de formação de professores de 
História não são muitos. O controle que firmamos nessa área indica que a maior parte dos estudos que vinculam formação docente e as leis relacionadas à alteração do artigo 26 da Lei de Diretrizes e Bases da Educação se volta para a formação continuada (muito provavelmente, em função dos inúmeros processos de formação oferecidos nos anos que se seguiram à aprovação da lei, seja por iniciativa das instituições de ensino superior, seja por fomento da SECADI) ${ }^{41}$ Benjamin Xavier de Paula e Selva Guimarães argumentam que o investimento na formação continuada foi visto como a alternativa para suprir a ausência de competências para o tratamento das questões étnicoraciais na formação inicial. ${ }^{42} \mathrm{Em}$ seu estudo, ambos apontam que a maior parte das pesquisas voltam-se para a formação continuada e nenhuma das que consideraram ocupa-se com os percursos curriculares de cursos de formação de professores de História.

Relativamente à área de História, um conjunto significativo de pesquisas volta-se para o campo do Ensino de História. José Ricardo Oriá Fernandes, por exemplo, depois de constatar que currículos, programas de ensino e livros didáticos são demarcados por uma perspectiva eurocêntrica, traça alguns dos desafios e das perspectivas para a implementação da lei, como inserção de disciplina ocupada com a trajetória histórica da África, o fomento à pesquisa em História da África e elaboração de material didático específico. ${ }^{43} \mathrm{Uma}$ das reflexões mais densas foi publicada cinco anos após a promulgação da lei, no entanto. Trata-se da reflexão acerca dos desafios que a lei colocava para o Ensino de História: a inclusão de outras perspectivas para além daquela consagrada e a ausência de professores capacitados para atender às expectativas da legislação, em função da formação recebida. Júnia Sales Pereira enfrenta os desafios da legislação, apontando os riscos a que a área está sujeita, especialmente o uso político que dela pode ser feito, ${ }^{44}$ a partir de uma crítica às diretrizes que regulam a sua implementação. ${ }^{45}$ No que se refere à formação docente, a autora aponta algumas fragilidades nos processos de formação, como o enfrentamento da discussão sobre o racismo e seus desdobramentos, o que, para a autora resulta da "precariedade da exploração das interfaces entre a história, a sociologia e a antropologia" nos percursos de formação. É o Ensino de História na escola, todavia, o que ocupa sua atenção e, nesse sentido, a autora argumenta o seguinte:

A demanda pelo ensino de conteúdos específicos - nesse caso, o ensino de história e cultura afro-brasileira - requer uma tradução pela ação docente em história, não somente pela sua introdução no currículo escolar, mas sobretudo por uma recomposição de concepções de história - a partir de então pautadas pela revisão das abordagens chamadas eurocêntricas e colonialistas. 
Embora a lei preveja a obrigatoriedade de alguns conteúdos no ensino de história, ele virá a impactar não apenas na organização, seleção e elenco de temáticas. Uma das principais decorrências de sua recepção pela escola é o movimento de reconfiguração de narrativas nas aulas de história, em que o Brasil afro-brasileiro (e sua ancestralidade histórica) passa a ser compreendido de forma positivada - o mesmo poderá ser dito sobre a história africana. ${ }^{46}$

O Ensino de História, desde a promulgação da Lei $n^{\circ}$ 10.639/2003 e, por conseguinte, desde a alteração da Lei de Diretrizes e Bases da Educação, demanda, portanto, uma reconfiguração das perspectivas segundo as quais a História do Brasil vem sendo percebida.

Para Júnia Sales, isto tem desdobramentos nos processos de formação docente, em função dos compromissos éticos a que o Ensino de História passa a ser vinculado, posto não se resumir à inclusão de conteúdos, mas a atenção aos vícios do racismo e seus desdobramentos e ao seu combate. ${ }^{47}$

A formação docente emerge, então, como instância estratégica no processo de implementação da lei, pois, por meio dela, os futuros professores seriam capacitados não apenas em acordo com a crítica à perspectiva que tem pautado a constituição da memória histórica, mas, sobretudo, no domínio das competências e habilidades necessárias ao combate às diversas formas assumidas pelo racismo no ambiente escolar. Assim, consideramos que a análise sobre os percursos curriculares dos cursos de formação de professores de História deve atentar para três aspectos, especialmente. Em primeiro lugar, para o modo pelo qual os percursos curriculares incorporam à crítica subjacente à legislação. É necessário dimensionar como os cursos (mais que adicionar conteúdos à grade curricular) encaminham uma crítica à perspectiva eurocêntrica e atentam para outras perspectivas na abordagem da trajetória histórica brasileira. Em segundo lugar, há que se considerar como tais percursos encaminham discussões necessárias ao exercício da docência: que saberes são privilegiados e como eles se articulam para a constituição das competências e habilidades requeridas pela escola e pelos sistemas de ensino. Tendo em vista que a legislação tem por objetivo o combate às diversas formas que o racismo assume no ambiente escolar e à oferta de uma educação antirracista, é fundamental, finalmente, que se perscrute como os percursos de formação se instrumentalizam para formar professores atentos para essa questão tão complexa quanto sensível.

Iniciemos, então, pela perspectiva que demarca os cursos de formação que analisamos. $\mathrm{Na}$ seção anterior, já apontamos o lugar que ocupam as disciplinas de caráter historiográfico e teóricometodológicas. Voltemos a esse conjunto de disciplinas, pois, destarte 
é possível verificar o lugar que a crítica à perspectiva eurocêntrica e a abertura para outras perspectivas ocupam nos percursos curriculares estudados. Inicialmente, verificamos o espaço destinado às disciplinas de caráter historiográfico e àquelas voltadas para os conteúdos teóricometodológicos em relação à carga horária total dos cursos, dada a importância de tais disciplinas, conforme gráfico apresentado antes.

Para tanto, reunimos as disciplinas em grupos, conforme as seguintes categorias: a) Propedêuticas: disciplinas voltadas para conteúdos de natureza instrumental, como Português Instrumental, por exemplo; b) Historiográficas: as disciplinas voltadas para o estudo do saber historiográfico relativo a períodos [Antiguidade, Idade Média, Idade Moderna e Idade Contemporânea] ou para espaços [História do Brasil, História da América e História Local/Regional]; c) Teóricas: disciplinas relativas à trajetória da disciplina e ao estudo dos procedimentos metodológicos e da produção acumulada [Teorias da História, Metodologias da Pesquisa e Historiografias]; d) Disciplinas relacionadas à satisfação do disposto no artigo 26 da Lei de Diretrizes e Bases da Educação: disciplinas que objetivam dar conta da inclusão dos conteúdos expressos na legislação [História da África, História Indígena, Cultura Afro-Brasileira]; e) Patrimônio: disciplinas voltadas para a discussão das formas de manutenção e preservação do patrimônio histórico; f) Formação Docente: disciplinas veiculadas aos saberes da docência, expressas em nucleações assim identificadas [Didáticas, Metodologias do Ensino, Psicologias, Língua Brasileira de Sinais etc.]; g) Interdisciplinaridade: disciplinas que demarcam o diálogo com outras áreas do conhecimento [Antropologia, Filosofia, Sociologia etc.]; h) Monografia: disciplinas comprometidas com a elaboração do trabalho de conclusão de curso, independentemente de sua conformação específica em cada uma das instituições estudadas; i) Prática como Componente Curricular [PCC]: as disciplinas que atendem à exigência de 400 horas de prática, conforme demanda a legislação; ${ }^{48}$ j) Estágio Supervisionado: as disciplinas que atentem à exigência de 400 horas de estágio, conforme demanda a legislação; k) Optativas: disciplinas escolhidas ou eleitas pelos alunos, em função de seus interesses, conforme previsão curricular; 1) Atividades Acadêmico Científico-Culturais: atividades acadêmicas que devem abarcar 200 horas de carga horária efetiva, conforme a legislação pertinente. ${ }^{49}$ 
TABELA II. Categorização da Distribuição da Carga Horária dos Cursos (percentual)

\begin{tabular}{|c|c|c|c|c|c|c|c|c|c|c|}
\hline \multirow[b]{2}{*}{ Categorias } & \multicolumn{10}{|c|}{ Instituições } \\
\hline & 毫 & 岁 & 哭 & $\sum_{\text {昱 }}^{E}$ & $\sum_{y}^{0}$ & $\begin{array}{l}\text { 器 } \\
\text { 严 }\end{array}$ & 高 & 㞼 & 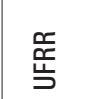 & 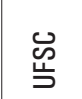 \\
\hline Propedêuticas & 1,75 & 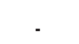 & & . & 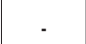 & . & 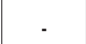 & . & . & \\
\hline Historiográficas & 32,46 & 32,01 & 36,45 & 35,26 & 23,53 & 31,42 & 28,53 & 30,76 & 29,88 & 27,8 \\
\hline Teóricas & 10,53 & 13,71 & 13,68 & 14,32 & 17,11 & 15,2 & 12,3 & 5,77 & 10,68 & 10,7 \\
\hline Artigo 26/LDB & 3,51 & 2,29 & 7,98 & 2,2 & 2,14 & 2,03 & 3,93 & 0 & 0 & 2,14 \\
\hline Patrimônio & 1,75 & - & . & . & . & . & . & . & . & - \\
\hline Formação docente & 8,77 & 9,14 & 13,68 & 12,48 & 8,56 & 18,24 & 17,7 & 13,46 & 8,54 & 11,59 \\
\hline Interdisciplinaridade & 3,51 & - & 2,28 & 12,12 & . & 2,03 & 1,97 & 9,62 & 2,14 & - \\
\hline Monografia & 3,51 & - & . & 3,67 & . & 7,09 & 3,93 & 11,54 & 5,34 & 5,35 \\
\hline PCC & 12,28 & 13,71 & - & 1,59 & 4,28 & . & . & . & 14,23 & 8,73 \\
\hline $\begin{array}{l}\text { Estágio } \\
\text { Supervisionado }\end{array}$ & 12,28 & 14,29 & 14,25 & 12,24 & 22,99 & 7,09 & 13,28 & 9,62 & 15,66 & 14,44 \\
\hline Optativas & 3,51 & 7,71 & 4,56 & . & 13,9 & 10,14 & 11,8 & 19,23 & 6,41 & 12,12 \\
\hline Atividades & 6,14 & 7,14 & 7,12 & 6,12 & 7,49 & 6,76 & 6,56 & & 7,12 & 7,13 \\
\hline
\end{tabular}

Fonte: Elaborado pelos autores a partir dos Projetos Político-Pedagógicos dos cursos das respectivas instituições, fev.2018.

Conforme a tabela II, as disciplinas Historiográficas e Teóricas compreendem a maior parcela de carga-horária, em todos os percursos curriculares. Isso sugere duas coisas: primeiramente, o lugar central das discussões acerca do saber de referência nos percursos de formação de professores de História (há extensa bibliografia sobre isso, ${ }^{50}$ de modo que não nos ocuparemos deste aspecto aqui); depois, que tais discussões ocupam espaço estrutural na formação ofertada, indicando não apenas de que História se está tratando, mas, sobretudo, da 
perspectiva privilegiada pelos cursos de formação. Considerá-las, então, nos permite problematizar o modo como outras perspectivas, além das assumidas a partir da Europa, são incorporadas na discussão sobre o saber histórico acumulado e sobre os temas eleitos pela legislação.

Tomamos como base para análise as ementas das disciplinas e a bibliografia básica arrolada. Nelas, considerando a técnica de análise de conteúdo, verificamos não somente as referências aos espaços, mas como estes encaminhavam a matriz a partir da qual a discussão proposta se desenvolvia. Constatamos que as ementas referenciavam os espaços de duas formas. Por um lado, indicando o lugar do qual se falava, assim o texto situava o recorte espacial que demarcava a discussão a ser realizada pela disciplina:

Dinâmica dos processos históricos nos seus aspectos sociais, econômicos, políticos e culturais, da Europa na Era Moderna. ${ }^{51}$

Transformações econômicas e sociais a partir da segunda metade do séc. XVIII. Iluminismo e despotismo reformista. Revolução Francesa e período napoleônico, A cidadania moderna. Surgimento e transformações da indústria. Liberalismo e capitalismo industrial. Mercado mundial e novas formas de colonização. Trabalhadores rurais e urbanos na segunda metade do século XVIII e durante o século XIX. Revoluções liberais e democráticas. Processos de unificação nacional, Estado-nação e nacionalismos. Pensadores e movimentos críticos do capitalismo. Circulação de ideias, experiências e culturas do século XVIII ao XIX. ${ }^{52}$

Por outro lado, as ementas indicavam o espaço a partir do qual se falava, estabelecendo o nexo que atribuía sentido à discussão a ser conduzida pela disciplina:

Análise da produção historiográfica. A expansão marítima europeia e o descobrimento do Brasil. A exploração e colonização e sua relação com o meio ambiente com. A sociedade colonial: vida, imaginário, comportamento e transgressão. As invasões francesas. A ocupação holandesa em Pernambuco e Maranhão, os movimentos nativistas. A transmigração da família real. O ensino da história da colonização portuguesa e da participação africana na escola básica. ${ }^{53}$

Estudo das diferentes estruturas sócio-políticas da África entre os séculos XVI e $\mathrm{XX}$, os processos de constituição dos sistemas coloniais e de descolonização e as formas de abordagens didático-pedagógicas. ${ }^{54}$ (UFSC, p. 72)

Nesse último caso, nossa intenção era perceber como dado espaço era percebido pela ementa.

Com base no procedimento adotado, formulamos uma topografia das disciplinas historiográficas e teórico-metodológicas. 
GRÁFICO II. Topografia das Disciplinas

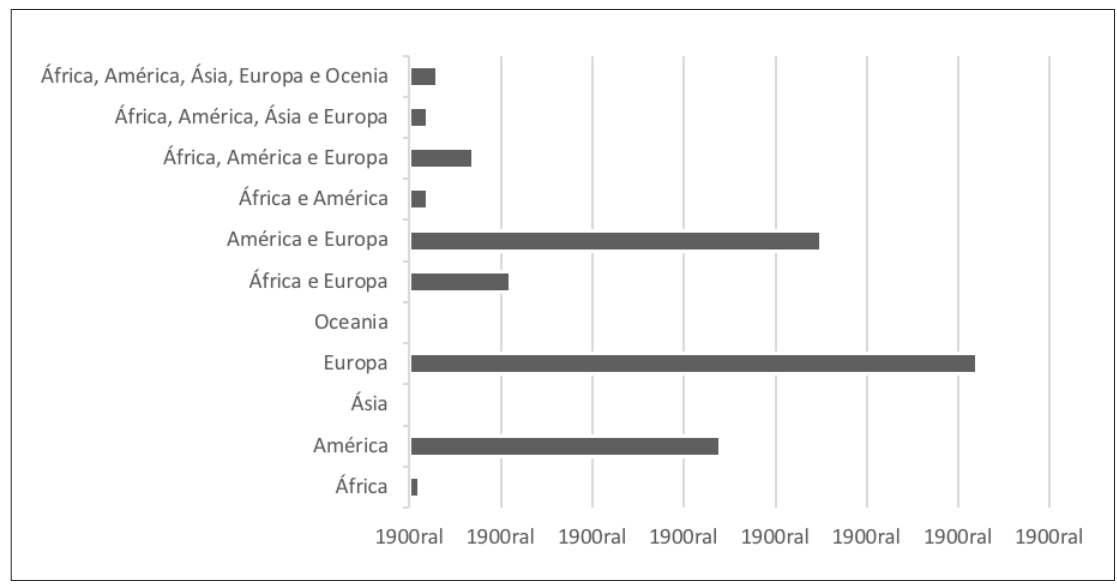

Fonte: Elaborado pelos autores a partir dos Projetos Político-Pedagógicos dos cursos das respectivas instituições, fev.2018.

O gráfico II aponta alguns dados importantes para a discussão que realizamos. Salta aos olhos o volume do espaço europeu nos currículos de formação. A Europa é espaço absoluto de atenção em disciplinas voltadas para a compreensão de processos que nela ocorreram, como é o caso de História Antiga, História Medieval, História Moderna e História Contemporânea. Em seguida, a mesma Europa aparece como epicentro dos eventos que regulam processos em outras partes do globo - situação frequente em disciplinas voltadas para o trato com os processos de colonização da América (seja tratando do continente, nas disciplinas regularmente denominadas de História da América I, seja nas disciplinas voltadas para a abordagem da História do Brasil, identificadas, via de regra pelo numeral romano I), mas presentes também em disciplinas relativas à História da África, História Indígena, História da América ou do Brasil independentes e nas disciplinas de natureza teórico-metodológica. Nestas últimas, é meramente incidental a referência às perspectivas decoloniais que buscam estabelecer uma crítica à orientação eurocêntrica.

Disso resulta que, a despeito das referências críticas à adoção de perspectivas unilaterais e a atenção à legislação que pauta a incorporação de outras histórias, os currículos permanecem fiéis a uma tradição que vê a História como uma prerrogativa europeia. A crítica de Manuela Carneiro da Cunha acerca do lugar da Europa como epicentro da História permanece, portanto, atual. ${ }^{55}$ Mas, não só. A considerar os recortes que acionamos, os cursos de formação de professores de História mantêm-se fiéis à posição segundo a qual a formação docente constitui aspecto secundário ou acessório nos percursos curriculares. 
Verificamos, nesse sentido, um certo descompasso entre as diretrizes para a formação do Historiador, referida páginas atrás, e aquelas formuladas para a formação docente, em vigor ao tempo de elaboração dos Projetos Político-Pedagógicos aqui estudados. Segundo apontam as Diretrizes Curriculares Nacionais para a Formação de Professores, as competências a serem desenvolvidas nos egressos em cursos de formação docente devem estar relacionadas ao desenvolvimento e aprimoramento do domínio sobre as práticas pedagógicas que serão realizadas ao longo de seu percurso profissional - sem esquecer, evidentemente, os conteúdos específicos de cada saber de referência. ${ }^{56}$

Dentre tais competências, as diretrizes destacam: "comprometimento com os valores inspiradores da sociedade democrática", "compreensão do papel social da escola", "domínio dos conteúdos a serem socializados, aos seus significados em diferentes contextos e sua articulação interdisciplinar" e "domínio do conhecimento pedagógico". O domínio dos saberes de referência é, portanto, uma das competências a serem desenvolvidas ao longo do processo de formação. As diretrizes o associam às demais competências, as quais lhe atribuem sentido - o domínio dos conteúdos a serem socializados conforma um conjunto de atributos que significam e especificam a ação docente. Esta, por sua vez, é relacionada a objetivos políticos - valorização da democracia e compreensão da escola como um espaço que vai além da reprodução de saberes, mas que assume função social, a qual constitui, entre outras ações, a promoção de "uma prática educativa que leve em conta as características dos alunos e de seu meio social, seus temas e necessidades do mundo contemporâneo e os princípios, prioridades e objetivos do projeto educativo e curricular" e "o compromisso da educação básica com a formação para a cidadania e buscam a mesma finalidade: possibilitar aos alunos a construção de significados e a necessária aprendizagem de participação social". ${ }^{57}$

A formação do professor deve, portanto, considerar como equivalentes os conteúdos relativos ao domínio do saber de referência e aqueles referentes ao domínio pedagógico. Essa articulação é vista como necessária para que a Educação cumpra sua função social - garantir inclusão. Isso significa promover uma Educação comprometida com os valores democráticos, com as prioridades do mundo contemporâneo e com a aprendizagem de formas de participação social. A luta contra as diversas expressões do Racismo e de seus desdobramentos - o preconceito e a discriminação - coadunase com as diretrizes para os cursos de formação de professores. Não 
por outra razão, as Diretrizes Curriculares para a Educação para as Relações Étnico-Raciais voltam-se para estes atores fundamentais na concretização de uma educação democrática - os professores. ${ }^{58}$

Recorrendo à mesma técnica de análise de conteúdo, nos debruçamos sobre os perfis de egresso, de modo a dimensionar as competências privilegiadas pelos percursos curriculares dos cursos de formação docente que analisamos. Das dez instituições, apenas a Universidade Federal do Rio de Janeiro não disponibiliza o perfil do egresso no Projeto Político Pedagógico acessível em seu sítio na rede mundial de computadores. As demais instituições reúnem 104 indicações de perfil, as quais foram reunidas em 26 categorias. $\mathrm{Na}$ formulação destas categorias, buscamos nos aproximar das intenções presentes nos Projetos Político-Pedagógicos que estudamos. Operamos, a seguir, com aquelas que reuniram mais de uma instituição. Assim, apresentaremos a seguir uma tabela arrolando onze categorias, em relação as quais constatou-se incidência em mais de um percurso curricular. A tabela indica a categoria, seu descritor, o número de verbetes no conjunto estudado e as instituições que a veiculam.

TABELA III. Perfis de Egresso categorizações e incidência em Projetos Político-Pedagógicos

\begin{tabular}{|l|l|c|l|}
\hline \multicolumn{1}{|c|}{ Categoria } & \multicolumn{1}{|c|}{ Descrição } & Indicações & Instituições \\
\hline $\begin{array}{l}\text { Atuação na } \\
\text { Educação Básica }\end{array}$ & $\begin{array}{l}\text { Atuar na Educação Básica, ensinando, } \\
\text { pesquisando e concorrendo para a melhoria } \\
\text { das condições de oferta. }\end{array}$ & 11 & $\begin{array}{l}\text { UNIFAP, } \\
\text { UFG, UFPI, } \\
\text { UFSC. }\end{array}$ \\
\hline $\begin{array}{l}\text { Domínio da } \\
\text { Historiografia }\end{array}$ & $\begin{array}{l}\text { Conhecer a produção historiográfica, } \\
\text { identificando as diversas interpretações. }\end{array}$ & 15 & $\begin{array}{l}\text { UNIFAP, } \\
\text { UFC, UFG, } \\
\text { UFMG, } \\
\text { UFMT, UFPI, } \\
\text { UFPR, UFRR. }\end{array}$ \\
\hline $\begin{array}{l}\text { Domínio das } \\
\text { Tecnologias de } \\
\text { Informação }\end{array}$ & $\begin{array}{l}\text { Conhecer as tecnologias de informação, de } \\
\text { forma a aplica-las ao Ensino. }\end{array}$ & 2 & UFG, UFPI. \\
\hline $\begin{array}{l}\text { Domínio do Currículo } \\
\text { da Educação Básica }\end{array}$ & $\begin{array}{l}\text { Conhecer os conteúdos básicos previstos } \\
\text { pelo Currículo da Educação Básica. }\end{array}$ & 3 & $\begin{array}{l}\text { UFP, UFPR, } \\
\text { UFRR. }\end{array}$ \\
\hline $\begin{array}{l}\text { Domínio } \\
\text { Interdisciplinar }\end{array}$ & $\begin{array}{l}\text { Fomentar o diálogo entre a História e } \\
\text { outras disciplinas. }\end{array}$ & 5 & $\begin{array}{l}\text { UFC, UFMT, } \\
\text { UFPR, UFRR, } \\
\text { UFSC }\end{array}$ \\
\hline Postura Profissional & $\begin{array}{l}\text { Saber posicionar-se com autonomia, } \\
\text { demonstrar formação sólida, pautar-se por } \\
\text { princípios éticos. }\end{array}$ & 7 & $\begin{array}{l}\text { UNIFAP, } \\
\text { UFG, UFMT, } \\
\text { UFSC. }\end{array}$ \\
\hline
\end{tabular}




\begin{tabular}{|l|l|c|l|}
\hline $\begin{array}{l}\text { Produção de } \\
\text { Recursos Didáticos }\end{array}$ & $\begin{array}{l}\text { Desenvolver recursos didáticos que } \\
\text { promovam a aprendizagem em História }\end{array}$ & 2 & UFPI, UFSC. \\
\hline Produzir Pesquisa & $\begin{array}{l}\text { Saber produzir conhecimento em âmbito } \\
\text { acadêmico e difundi-lo. }\end{array}$ & 6 & $\begin{array}{l}\text { UFC, UFPR, } \\
\text { UFRR, UFSC. }\end{array}$ \\
\hline $\begin{array}{l}\text { Produzir pesquisa em } \\
\text { Ensino de História }\end{array}$ & $\begin{array}{l}\text { Saber produzir conhecimento voltada para 0 } \\
\text { Ensino de História. }\end{array}$ & 2 & UFG, UFPI. \\
\hline $\begin{array}{l}\text { Produzir pesquisa em } \\
\text { História }\end{array}$ & $\begin{array}{l}\text { Saber produzir conhecimento relativo } \\
\text { à historiografia ou às relaç̃os sócio- } \\
\text { históricas em diversos tempos e espaços. }\end{array}$ & 21 & $\begin{array}{l}\text { UFMG, } \\
\text { UFMT, UFPI, } \\
\text { UFPR, UFRR, } \\
\text { UFSC. }\end{array}$ \\
\hline $\begin{array}{l}\text { Transpor } \\
\text { didaticamente }\end{array}$ & $\begin{array}{l}\text { Saber transmitir conhecimento histórico na } \\
\text { Educação Básica. }\end{array}$ & 11 & $\begin{array}{l}\text { UFG, UFMG, } \\
\text { UFPI, UFPR, } \\
\text { UFRR, UFSC. }\end{array}$ \\
\hline
\end{tabular}

Fonte: Elaborado pelos autores a partir dos Projetos Político-Pedagógicos dos cursos das respectivas instituições, fev.2018.

Notem que apenas duas categorias estão presentes na quase totalidade dos cursos cujos perfis são disponibilizados - Domínio da Historiografia e Produzir pesquisa em História. Os perfis de egresso evidenciam, portanto, que as competências valorizadas pelos cursos de formação são o domínio da produção historiográfica e a produção de pesquisa sobre processos históricos. Ambas competências inerentes ao exercício do ofício de historiador. ${ }^{59}$ Causa espécie, todavia, o fato de os cursos de formação docente não distinguirem, da mesma forma, as competências necessárias ao exercício da docência. Dentre estas, a mais valorizada é a relativa à transposição didática, mencionada em apenas seis dos dez cursos estudados, sugerindo que a concepção de formação de professor, apesar das mudanças ocorridas ultimamente, permanece percebida como uma instrumentalização do saber de referência para fins didáticos.

É significativo, nesse sentido, que algumas competências sublinhadas pelas diretrizes curriculares para os cursos de formação docente, em vigor ao tempo de formulação dos Projetos PolíticoPedagógicos em questão, e as diretrizes para a educação para as relações étnico-raciais não tenham sido incorporadas por eles. O que os projetos em estudo apontam é que o conhecimento da produção historiográfica e dos procedimentos da pesquisa histórica seriam suficientes para enfrentar os desafios propostos pela legislação que pauta a inclusão, como a evasão, a distorção idade-série, as questões 
relativas à aprendizagem, entre outros problemas que atingem a Escola e, nela, de modo dramático, os alunos negros e pardos. ${ }^{60}$

Da mesma forma, é de se estranhar que aspectos das discussões relativas à formação docente, entendidas pela legislação como percurso específico e independente, sejam tão pouco referidas nos perfis de egresso. Diante disto, perscrutamos a concepção de formação docente subjacente ao percurso curricular, considerando as disciplinas ali presentes. Nos deparamos, então, com um conjunto diverso de denominações que evidenciam as preocupações de cada corpo docente responsável pela formulação dos percursos analisados aqui, de modo que agregamos as disciplinas segundo categorias: a) Metodologia do Ensino de História - reunindo disciplinas que se ocupam com as questões relativas ao ensino do saber de referência, sob qualquer perspectiva; b) Didática - reunindo disciplinas que abordam as questões da didática geral; c) Introdução à Educação - reunindo disciplinas que tratam de princípios teóricos e filosóficos da Educação; d) Psicologia da Educação - reunindo disciplinas que trabalham com as diferentes psicologias (da aprendizagem, da Infância e da Adolescência); e) Estrutura política e gestão educacional - reunindo disciplinas voltadas para a reflexão sobre as políticas educacionais, o currículo da Educação Básica e os problemas da Escola; f) Sociologia da Educação - reunindo disciplinas que se voltam para os estudos sociológicos relativos à Educação; g) Organização e funcionamento da Educação Básica - reunindo disciplinas voltadas para a reflexão sobre os níveis da Educação Básica e os sistemas de ensino; h) História da Educação - disciplinas ocupadas com a sistematização da história da educação, estabelecendo periodizações, historiografia etc.

Pois bem, consideramos, novamente, os casos nos quais notamos a incidência do grupo de disciplinas em mais de uma instituição. Constatamos que as psicologias estão presentes em todos os percursos curriculares, com ênfase para a aprendizagem. Os grupos de disciplinas voltados para as didáticas e para a estrutura política e a gestão educacional estão presentes em 70\% dos percursos curriculares. Todos as outras categorizações têm incidência igual ou inferior a $40 \%$. Tais características dos percursos curriculares nos levou a duas conclusões preliminares. Em primeiro lugar, há diferenças sobre que competências concorrem para a formação de professores de História. Em segundo lugar, tais diferenças não superam uma compreensão hegemônica: as competências docentes valorizadas por quase todos os cursos são aquelas que dizem respeito ao imperativo da transmissão do saber de referência - as psicologias de aprendizagem e as didáticas. Cabe, no entanto, considerar o espaço de tais disciplinas nos percursos curriculares. 
Os Projetos Político-Pedagógicos compreendem um conjunto de atividades obrigatórias, definidas pela legislação relativa aos cursos de formação de professores. Assim, os cursos de formação em estudo teriam de reservar uma parte da carga horária para a Prática como Componente Curricular, o Estágio Supervisionado e as Atividades AcadêmicoCulturais. Elas compreendem mil horas-aula, independentemente da carga horária total do curso. As demais atividades resultam do arbítrio dos corpos docentes das instituições. É ele que decide e define que outras atividades conformarão o percurso curricular.

Reformulamos, então, a tabela II, retirando delas os dados referentes às atividades obrigatórias. Nosso objetivo foi dimensionar o espaço destinado à formação docente pelos professores dos cursos que tratamos. Os percentuais expressos são relativos à carga horária de arbítrio das instituições, definidas e distribuídas em acordo com a concepção de formação de professores compartilhada pelos docentes dos cursos superiores. Vejamos, então, a nova formatação da tabela:

TABELA IV. Distribuição dos componentes curriculares, segundo 0 arbítrio das instituições (\%)

\begin{tabular}{|c|c|c|c|c|c|c|c|c|c|c|}
\hline Componentes & 毫 & 岀 & 号 & 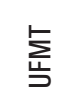 & $\sum_{\stackrel{S}{S}}^{G}$ & $\begin{array}{l}\text { 敩 } \\
\frac{1}{3}\end{array}$ & 案 & 嵒 & $\begin{array}{l}\text { 䍃 } \\
\frac{1}{5}\end{array}$ & 总 \\
\hline Propedêutica & 2,53 & - & - & & - & - & - & - & & - \\
\hline Historiográfica & 46,82 & 49,35 & 46,39 & 44,02 & 36,07 & 36,49 & 35,58 & 34,06 & 47,46 & 39,91 \\
\hline Teóricas & 15,19 & 21,15 & 17,39 & 17,89 & 26,23 & 17,65 & 15,34 & 6,38 & 16,95 & 15,35 \\
\hline Artigo 26/LDB & 5,06 & 3,52 & 10,14 & 2,75 & 3,28 & 2,35 & 4,91 & - & - & 3,07 \\
\hline Patrimônio & 2,53 & - & - & - & - & - & - & - & - & - \\
\hline Formação docente & 12,66 & 14,1 & 17,39 & 15,6 & 13,11 & 21,18 & 22,09 & 14,89 & 13,56 & 16,62 \\
\hline Interdisciplinaridade & 5,06 & - & 2,9 & 15,14 & - & 2,35 & 2,45 & 10,64 & 3,39 & - \\
\hline Monografia & 5,06 & - & - & 4,59 & 21,31 & 8,24 & 4,91 & 12,77 & 8,47 & 7,67 \\
\hline Optativas & 5,06 & 11,89 & 5,8 & - & - & 11,76 & 14,72 & 21,28 & 10,17 & 17,39 \\
\hline
\end{tabular}

Fonte: Elaborado pelos autores a partir dos Projetos Político-Pedagógicos dos cursos das respectivas instituições, fev.2018. 
A tabela indica que se, por um lado, há algumas diferenças na distribuição da carga horária, considerando os projetos estudados, há consenso quanto ao espaço que as disciplinas de caráter pedagógico ocupam nos percursos curriculares. Como se vê, tais disciplinas representam menos de $1 / 4$ da carga horária de formação a critério do corpo docente das universidades. Quando relacionamos o volume de carga horária e a matriz curricular de formação pedagógica nos cursos estudados, a conclusão possível é de que ela é insuficiente para dar conta dos desafios da Escola e, especialmente, dos dilemas e questões que uma educação antirracista coloca.

Isto nos leva à segunda conclusão preliminar, relativamente à questão que tratamos. O espaço destinado às questões pedagógicas não dá conta de aspectos fundamentais para o combate ao racismo, como a compreensão da Escola no mundo contemporâneo, o estudo de aspectos sociais que afetam, especialmente (mas, não só), crianças e adolescentes em situação de vulnerabilidade, a problematização das diversas formas assumidas pelo racismo na Escola, a pesquisa sobre a criança e o adolescente no mundo contemporâneo, a reflexão sobre o descompasso entre o que a Escola valoriza e as expectativas das atuais gerações de crianças e adolescentes, em meio a um conjunto enorme de questões que afetam a vida escolar e tem impacto direto na perpetuação do racismo.

Esse ponto nos leva à última parte de nosso artigo: o modo como os percursos curriculares atentam para as Diretrizes Curriculares Nacionais para a Educação das Relações Étnico-Raciais e para o Ensino de História e Cultura Afro-Brasileira e Africana. Nosso propósito é verificar como os objetivos da legislação, especialmente a formação voltada para o combate ao racismo e às diversas formas assumidas por ele nas relações sociais vividas no Brasil, são enfrentados pelos projetos político-pedagógicos analisados. A finalidade da lei, conforme já exposto, não é exaurida pela inclusão de disciplinas, antes, conforma uma discussão mais ampla, que incorpora as concepções sobre Diferença e Diversidade e, sobretudo, sobre os princípios que pautam uma Educação fundada na Inclusão e na defesa da Democracia.

É importante ressaltar o significativo volume de estudos voltados para as diversas formas assumidas pelo racismo na Escola. ${ }^{61}$ Estes trabalhos apontam que invisibilidade do Negro (e do Índio) não se limita à falta de referências à África e à Cultura Afro-Brasileira (e à trajetória dos povos indígenas). Ela se expande à forma como crianças negras e pardas são percebidas e tratadas pela e na Escola e pelo e no sistema escolar. As pesquisas sugerem que práticas racistas e discriminatórias, naturalizadas pela cultura brasileira, constituem 
o cotidiano escolar - elas vão desde o modo pelo qual a atenção é dispensada pelos professores aos alunos à expectativa que professores e gestores manifestam em relação a estudantes, numa gradação que corresponde ao gradiente que demarca a sociedade brasileira.

Pois, o que verificamos é que as expectativas da legislação são cumpridas, via de regra, de modo burocrático pelos corpos docentes dos cursos de formação de professores que estudamos. A impressão que se tem - e se trata, efetivamente, de uma impressão, posto que baseada nos anos de estudo que acumulamos e no trato com diversas instituições - é de que os corpos docentes praticam uma leitura instrumentalizada da legislação, a qual se limita às resoluções. Os pareceres que as fundamentam e que dão corpo aos dispositivos legais parecem ser desconsiderados. Eles são importantes, no entanto, porque não se limitam à prescrição, pois dimensionam os dispositivos de modo a apontar seus objetivos e impactos, situando as diretrizes como algo mais que ordenações. Os pareceres apontam a trajetória da discussão, indicam suas motivações e as implicações que lhe são relacionadas. Não obstante, nossa impressão (reforçada pelos dados que computamos) é que as resoluções são seguidas formalmente sem que se atente para os seus fundamentos. Senão, vejamos.

Precisamos retornar à tabela III. Ao buscarmos computar o percentual de carga horária relativa à satisfação da legislação que altera o artigo 26 da Lei de Diretrizes e Bases da Educação, nos deparamos com a ausência das questões previstas pelas Diretrizes para Educação das Relações Étnico-Raciais das discussões levadas a cabo pelas disciplinas. Daí, nos voltarmos para as disciplinas que tratam dos conteúdos previstos pela legislação: História da África e Cultura Afrobrasileira. Nesse caso, um outro movimento foi necessário: em relação à História da África, consideramos as disciplinas que fazem referência à África Negra. Optamos por esse recorte, pois há referências à África Mediterrânica em disciplinas de História Antiga e História Medieval, quando se trata das grandes civilizações e dos povos árabes (como é caso dos Projetos Político-Pedagógicos da UNIFAP, UFC, UFMT, UFRR e UFSC). Também verificamos referências à África na disciplina História da Arte, quando aborda as manifestações artísticas não-ocidentais (é o caso da UFG). ${ }^{62}$ Diante disso, consideramos as disciplinas nas quais a África Negra e/ou a Cultura Afro-Brasileira constituem o escopo da discussão proposta pela ementa e pela bibliografia. Antes de abordálas, vejamos então, que disciplinas buscam dar conta do que prevê o artigo 26-A da LDB: Cultura Afro-brasileira (UFPI), História Africana e Afro-Brasileira (UNIFAP), História Indígena (UNIFAP), História 
da África (UFC, UFMT, UFMG, UFPR e UFSC), História da América Afro-portuguesa (UFPI), História da Cultura Afro-brasileira (UFG) e História e Cultura Indígena (UFG) e Laboratório de Ensino de História (UFSC). Os projetos que analisamos, das instituições do Rio de Janeiro e de Roraima, não apontam disciplinas obrigatórias voltadas para o escopo da legislação - daí sua ausência do quadro apresentado.

A inclusão de tais disciplinas parece buscar satisfazer, formalmente, aquilo que a legislação prevê, sem a alteração da estrutura que vem conformando os cursos de História há décadas. Não por outra razão, argumentamos, a concretização da legislação em termos de percurso curricular é percebida, pela maior parte dos cursos, como inclusão de conteúdos - marcadamente de natureza histórica. As histórias da África, dos Povos Indígenas e da Cultura Afro-brasileira concentram os esforços de cumprimento da legislação. Isso não quer dizer, porém, o abandono de uma perspectiva que percebe a Europa como epicentro da História. A considerar as ementas e a bibliografia básica arrolada nos Projetos Político-Pedagógicos sobre os quais nos debruçamos, a Europa é percebida como o fator a partir do qual os eventos ocorridos em África e na América ganham sentido e é de lá, também, que são conformados os aportes teóricos que permitem a leitura dos processos vividos nos dois espaços. ${ }^{63}$

Isso resulta da concepção de formação docente presente nos cursos estudados. O saber de referência permanece sendo visto como o apanágio a sustentar as ações dos professores de História na Educação Básica. Ele, todavia, permanece atrelado a uma perspectiva que vê na Europa não somente a matriz que dá inteligibilidade à disciplina, mas que percebe o Velho Continente, senão como o epicentro, como o fator determinante da história vivida em qualquer parte do globo. Os percursos curriculares apontam que é o domínio da produção historiográfica e dos procedimentos de pesquisa histórica assim percebidos os campos que concentram a maior parte da carga horária dos cursos de formação de professores de História. Essa conformação aponta duas coisas. De um lado, a relevância dada ao saber de referência sugere que os saberes da docência são de natureza instrumental - destinados a garantir a transposição do conhecimento produzido na Academia em saber a ser consumido pelos alunos da Educação Básica. De outro lado, o espaço destinado àquele saber em comparação com os saberes da docência sugere que o saber de referência é suficiente para o enfrentamento dos desafios que a Escola se depara - em particular, dado o nosso interesse neste artigo, a Educação para as Relações Étnico-Raciais. 
Sustenta o nosso argumento a quase total ausência das discussões que demarcam as Diretrizes Curriculares Nacionais para a Educação das Relações Étnico-Raciais e para o Ensino de História e Cultura Afro-Brasileira e Africana nos Projetos Político-Pedagógicos que estudamos. A reflexão sobre a Escola e especialmente sobre a Escola Pública, o estudo sobre a juventude (particularmente aquela situada nas periferias) e suas culturas, a discussão sobre o racismo e seus desdobramentos, a análise sobre as diversas formas que ele assume na sociedade e (especificamente) na Escola são temas e questões que não constituem preocupação relevante dos cursos de formação de professores que analisamos - seja porque são minimamente tratadas, seja porque não o são de modo algum.

Dos dez Projetos Político-Pedagógicos que analisamos, apenas um não faz referência à História da África e da Cultura Afro-Brasileira exclusivamente em disciplinas específicas para esse fim. Na Universidade Federal de Santa Catarina, as questões relativas à legislação são abordadas, também, pela disciplina Laboratório de Ensino de História. Nela, os desafios que se colocam diante do professor da Educação Básica são problematizados, por meio de uma bibliografia que enfrenta o debate e situa os aspectos centrais da discussão sobre o racismo no ambiente escolar. O mesmo não ocorre nas demais instituições.

\section{SEM CONCLUSÃO}

A política educacional da qual a Lei no 10.639/2003 faz parte permanece em discussão. Isto se deve, também, ao fato de tratar-se de uma política educacional, a qual merece avaliações permanentes, mas, bem como, em função dos desafios que ela coloca para os sistemas educacionais e as resistências que enfrenta para ser implementada. ${ }^{64}$ Assumimos, neste artigo, uma posição singular, diante da crítica consolidada em relação à lei e aos seus desafios. Consideramos que os entraves experimentados pelos sistemas educacionais no processo de implementação são, em larga medida, decorrentes da formação inicial ofertada aos futuros professores.

A análise sobre percursos curriculares de cursos de formação de professores de História, nos permite afirmar ser menos a "precariedade da exploração das interfaces entre a história, a sociologia e a antropologia" que dificulta o enfrentamento da discussão sobre o racismo e seus desdobramentos. ${ }^{65}$ Os embaraços interpostos ao enfrentamento do racismo e seus desdobramentos no ambiente escolar são inversamente proporcionais ao espaço que a discussão 
sobre a Escola e sobre as competências necessárias ao exercício da docência ocupam nos cursos de formação de professores de História. Não é possível formar para a cidadania, formar para uma crítica à memória, formar para a conformação de uma sociedade que combate preconceitos se a discussão fundamental sobre a formação de crianças, adolescentes e adultos inseridos na Educação Básica ocupa, em média, a sexta parte da carga horária - retirando-se as disciplinas de caráter obrigatório, estipuladas pela legislação. ${ }^{66}$

Formar para o combate ao racismo e para a emergência e consolidação de uma sociedade democrática implica, antes de tudo, em saber formar. Daí nossa posição. Constatamos, como muitos antes de nós, do pouco espaço destinado à discussão sobre África e sobre a Cultura Afro-brasileira. Argumentamos, todavia, que esse pouco espaço decorre, sobretudo, da concepção sobre formação de professores e, nos casos dos cursos aqui estudados, da perspectiva preponderante nos percursos curriculares. Formar professores de História tem implicado, via de regra, na oferta de uma discussão arraigada na tradição disciplinar, pautada na divisão quadripartite, infensa à crítica à preponderância da perspectiva eurocêntrica e que assume a prática docente como uma instrumentalização do saber de referência para fins didáticos.

\section{REFERÊNCIAS:}

ARAÚJO, J. de A.; GIUGLIANI, B. Por uma educação das relações étnico-raciais. \#Tear: Revista de educação, ciência e tecnologia, Rio Grande do Sul, v. 3, n. 1, 2014. Disponível em: https://periodicos.ifrs.edu.br/index.php/tear/article/view/1833/1431. Acesso em: 14 dez. 2017.

BICALHO, P. S. dos S. As assembleias indígenas - o advento do movimento indígena no Brasil. Opsis, Catalão, v. 10, n. 1, p. 91-114, jan./jun. 2010. Disponível em: https://revistas. ufg.br/Opsis/article/view/9553/8474\#.Wn4GhGnwbIU. Acesso em: 14 dez. 2017.

BORJA, I. M. F. de S.; MARTINS, A. M. de O. Evasão escolar: desigualdade e exclusão social. Revista Liberato, Novo Hamburgo, v. 15, n. 23, p. 01-104, jan./jun. 2014. Disponível em: http://www.liberato.com.br/sites/default/files/arquivos/liberato_informa/liberato_ informa_02_de_julho.pmd_.pdf. Acesso em: 30 dez. 2018.

BRASIL. Constituição da República Federativa do Brasil de 1988. Disponível em: http://www.planalto.gov.br/ccivil_03/constituicao/constituicaocompilado.htm. Acesso em: 28 jan. 2018.

BRASIL. Lei $\mathbf{n}^{\mathbf{0}} \mathbf{1 0 . 6 3 9}$, de 9 de janeiro de 2003. Altera a lei ${ }^{\circ}$ 9.394, de 20 de dezembro de 1996, que estabelece as diretrizes e bases da educação nacional, para incluir no currículo oficial da rede de ensino a obrigatoriedade da temática "História e Cultura Afro-brasileira", 
e dá outras providências. Disponível em: http://www.planalto.gov.br/ccivil_03/leis/2003/ 110.639.htm. Acesso em: 05 nov. 2017.

BRASIL. Lei $\mathbf{n}^{\mathbf{0}}$ 9.394, de 09 de janeiro de 1996. Estabelece as Diretrizes e Bases da Educação Nacional. Disponível em: https://www.planalto.gov.br/ccivil_03/Leis/L9394. htm. Acesso em: 28 jan. 2018.

CAIMI, F. E. Por que os alunos (não) aprendem História? Reflexões sobre ensino, aprendizagem e formação de professores de História. Tempo, Niterói, v. 11, n. 21, p. 17-32, 2006. Disponível em: http://www.scielo.br/pdf/tem/v11n21/v11n21a03.pdf. Acesso em: 19 dez. 2017.

CAIMI, F. E.; OLIVEIRA, S. R. F. de. Progressão do conhecimento histórico entre o ensino fundamental e o ensino médio: um olhar sobre o livro didático. Acta Scientiarum, Maringá, v. 39, p. 483-495, 2017. Disponível em: http://periodicos.uem.br/ojs/index.php/ ActaSciEduc/article/view/29864/21106. Acesso em: 02 jan. 2018.

CANEN, A. Currículo para o Desafio à Xenofobia: algumas reflexões multiculturais na educação. Conhecimento \& Diversidade, v.6, n. 11, p. 89-98, 2014. Disponível em: https:// revistas.unilasalle.edu.br/index.php/conhecimento_diversidade/article/view/1742. Acesso em: 13 jan. 2018.

COELHO, M. C. História Indígena - provocações para os historiadores. História Viva (São Paulo), v. XI, p. 24-27, 2014.

COELHO, M. C.; COELHO, W. de N. B. "Jogando verde e colhendo maduro": historiografia e saber histórico escolar no ensino de História da África e da Cultura Afro-Brasileira. Territórios e Fronteiras, Cuiabá, v. 6, n. 3, p. 92-107, 2013. Disponível em: http://www.ppghis.com/ territorios\&fronteiras/index.php/v03n02/article/view/247/180. Acesso em: 02 jan. 2018.

COELHO, M. C.; COELHO, W. de N. B. A diversidade na história ensinada nos livros didáticos: mudanças e permanências nas narrativas sobre a formação da nação. História e Diversidade, Cáceres, v. 6, n. 1, p. 6-21, 2015. Disponível em: https://periodicos.unemat.br/ index.php/historiaediversidade/article/view/866/855. Acesso em: 02 jan. 2018.

COElHO, W. de N. B.; COELHO, M. C. (org.). Raça, Cor e Diferença: a escola e a diversidade. Belo Horizonte: Mazza, 2008.

COELHO, W. de N. B.; COELHO, M. C. Entre Virtudes e Vícios: educação, sociabilidades, cor e ensino de História. São Paulo: Editora Livraria da Física, 2014.

COELHO, W. de N. B.; COELHO, M. C. Os conteúdos étnico-raciais na educação brasileira: práticas em curso. Educar em Revista, Curitiba, n. 47, p. 67-84, mar./2013. Disponível em: http://www.scielo.br/pdf/er/n47/06.pdf. Acesso em: 28 nov. 2017.

COELHO, W. de N. B.; COELHO, M. C. Preconceito e discriminação para além das salas de aula: sociabilidades e cultura juvenil no ambiente escolar? Revista Instituto de Estudos Brasileiros, São Paulo, v. 62, p. 1-22, 2015. Disponível em: https://www.revistas.usp.br/rieb/ article/view/107185. Acesso em: 10 jan. 2018.

CONSELHO NACIONAL DE EDUCAÇÃO. Parecer CEN/CES 492/2001. Diretrizes Curriculares Nacionais dos cursos de Filosofia, História, Geografia, Serviço Social, Comunicação 
Social, Ciências Sociais, Letras, Biblioteconomia, Arquivologia e Museologia. Disponível em: http://portal.mec.gov.br/cne/arquivos/pdf/CES0492.pdf. Acesso em: 04 dez. 2017.

CONSELHO NACIONAL DE EDUCAÇÃO. Parecer CNE/CES 15/2005. Disponível em http://portal.mec.gov.br/cne/arquivos/pdf/pces0015_05.pdf. Acesso em: 20 nov. 2017.

CONSELHO NACIONAL DE EDUCAÇÃO. Parecer CNE/CP 2/2015. Diretrizes Curriculares Nacionais para a Formação Inicial e Continuada dos Profissionais do Magistério da Educação Básica. Disponível em: http://portal.mec.gov.br/index.php?option=com_ docman\&view $=$ download $\&$ alias $=17625$-parecer-cne-cp-2-2015-aprovado-9-junho2015\&category_slug=junho-2015-pdf\&Itemid=30192. Acesso em: 28 nov. 2017

CONSElHO NACIONAL DE EDUCAÇÃO. Parecer CNE/CP 3/2004. Diretrizes Curriculares Nacionais para a Educação das Relações Étnico-Raciais e para o Ensino de História e Cultura Afro-Brasileira e Africana. Disponível em http://portal.mec.gov.br/cne/ arquivos/pdf/003.pdf. Acesso em: 11 abr. 2013.

CONSELHO NACIONAL DE EDUCAÇÃO. Parecer CNE/CP 9/2001. Diretrizes Curriculares Nacionais para a Formação de Professores da Educação Básica, em nível superior, curso de licenciatura, de graduação plena. Disponível em: http://portal.mec.gov. br/cne/arquivos/pdf/009.pdf. Acesso em: 06 dez. 2017.

CONSELHO NACIONAL DE EDUCAÇÃO. Resolução CNE/CES 13/2002. Estabelece as Diretrizes Curriculares para os cursos de História. Disponível em: http:// portal.mec.gov.br/cne/arquivos/pdf/CES132002.pdf. Acesso em: 04 dez. 2017.

CONSELHO NACIONAL DE EDUCAÇÃO. Resolução CNE/CP 1/2002. Institui Diretrizes Curriculares Nacionais para a Formação de Professores da Educação Básica, em nível superior, curso de licenciatura, de graduação plena. Disponível em: http://portal.mec. gov.br/cne/arquivos/pdf/rcp01_02.pdf. Acesso em: 04 dez. 2017.

CONSELHO NACIONAL DE EDUCAÇÃO. Resolução CNE/CP 1/2004. Institui Diretrizes Curriculares Nacionais para a Educação das Relações Étnico-Raciais e para o Ensino de História e Cultura Afro-Brasileira e Africana. Disponível em http://portal.mec. gov.br/cne/arquivos/pdf/res012004.pdf. Acesso em: 11 abr. 2013.

CONSELHO NACIONAL DE EDUCAÇÃO. Resolução CNE/CP 2/2002. Institui a duração e a carga horária dos cursos de licenciatura, de graduação plena, de formação de professores da Educação Básica em nível superior. Disponível em: http://portal.mec.gov. br/cne/arquivos/pdf/CP022002.pdf. Acesso em: 28 dez. 2017.

CONSELHO NACIONAL DE EDUCAÇÃO. Resolução CNE/CP 2/2015. Define as diretrizes Curriculares Nacionais para a formação inicial em nível superior (cursos de licenciatura, cursos de formação pedagógica para graduados e cursos de segunda licenciatura) e para a formação continuada. Disponível em: http://portal.mec.gov.br/index. php?option $=$ com_docman\&view $=$ download\&alias $=70431$-res-cne-cp-002-03072015pdf\&category_slug=agosto-2017-pdf\&Itemid=30192. Acesso em: 28 nov. 2017.

CORDEIRO, A. F. M.; BUENDGENS, J. F. Preconceitos na escola: sentidos e significados atribuídos pelos adolescentes no ensino médio Cordeiro. Revista Semestral da Associação Brasileira de Psicologia Escolar e Educacional, São Paulo, v. 16, n. 1, p. 45-54, jan./jun. 
2012. Disponível em: https://abrapee.files.wordpress.com/2012/02/abrapee_v16n1-1.pdf. Acesso em: 10 jan. 2018.

CUNHA, M. C. da. Introdução a uma história indígena. In: CUNHA, M. C. da (org.). História dos Índios no Brasil. São Paulo: Companhia das Letras; Secretaria Municipal de Cultura; FAPESP, 1992.

DA MATTA, R. Relativizando: uma introdução à Antropologia Social. Petrópolis: Vozes, 1981.

DEBONA, J. J.; RIBEIRO, R. R. Relações de gênero e livro didático de história: uma abordagem possível? Revista Educação e Fronteiras On-Line, Dourados/MS, v.4, n.11, p. 126-143, mai./ago. 2014. Disponível em: http://ojs.ufgd.edu.br/index.php/educacao/ article/view/4368/pdf_238. Acesso em: 02 jan. 2018.

FERNANDES, F. R.; COELHO, M. C. C. "Ame-o ou emancipe-o": contradições da emancipação nos discursos, práticas e representações dos/sobre os povos indígenas no Brasil (1970/1980) In: COELHO, W. de N. B.; COELHO, M. C. (org.) Debates Interdisciplinares sobre Educação e Diversidade. São Paulo: Ed. Livraria da Física, 2018. p.15-48.

FERNANDES, J. R. O. Ensino de história e diversidade cultural: desafios e possibilidades. Cadernos CEDES, Campinas, v. 25, n. 67, p. 378-388, dez./2005. Disponível em: http:// www.scielo.br/pdf/ccedes/v25n67/a09v2567.pdf. Acesso em: 14 dez. 2017.

FERREIRA, M. de M.; FRANCO, R. Desafios do ensino de história. Estudos Históricos, Rio de Janeiro, vol. 21, nº 41, p. 79-93, jan.-jun./2008. Disponível em: http:/ /www.scielo.br/ pdf/eh/v21n41/05.pdf. Acesso em: 19 dez. 2017.

FORMARI, L. T. Reflexões acerca da reprovação e evasão escolar e os determinantes do capital. Revista Espaço Pedagógico, Passo Fundo, v. 17, n. 1, p. 112-124, jan./jun. 2010. Disponível em: http://seer.upf.br/index.php/rep/article/view/2027. Acesso em: 28 jan. 2018.

FREITAS, M. A. B.; TORRE, I. C. O papel do movimento indígena no processo de escolarização do ensino Superior na Amazônia. Olhares Amazônicos, Boa Vista, v. 4, n. 1, p. 748-761, jan./jun. 2016. Disponível em: https://ufrr.br/roa/index.php/21-volume-4numero-1. Acesso em: 02 dez. 2017.

FURET, F. A oficina da História. Gradiva: Lisboa, s.d.

GERMINARI, G. D.; MOURA, A. F. de. Livro didático de história, entre conteúdos e epistemologia. Educação Unisinos, Rio Grande do Sul, v. 21, n. 1, p. 102-110, jan./ abr. 2017. Disponível em: http://revistas.unisinos.br/index.php/educacao/article/view/ edu.2017.211.11/5858. Acesso em: 02 jan. 2018.

GOMES, N. L. (org.). Práticas pedagógicas de trabalho com relações étnico-raciais na escola na perspectiva da Lei n. 10.639/2003. Brasília: MEC/UNESCO, 2012.

GOMES, N. L. G. O Movimento Negro educador: saberes construídos nas lutas por emancipação. Petrópolis: Vozes, 2017.

GONÇALVES, L. A.; SILVA, P. B. G. e. Movimento negro e educação. Revista Brasileira de Educação, Rio de Janeiro, n. 15, p. 134-158, set./dez. 2000. Disponível em http:// www.scielo.br/scielo.php?pid=S1413-24782000000300009\&script=sci_abstract\&tlng=pt. Acesso em: 10 jan. 2018. 
JESUS, R. E. Diversidade étnico-racial no Brasil: os desafios à Lei no 10.639, de 2003. Revista Retratos da Escola, Brasília, v. 7, n. 13, p. 399-412, jul./dez. 2013. Disponível em: http://retratosdaescola.emnuvens.com.br/rde/article/viewFile/314/484. Acesso em: 18 dez. 2017.

MARQUES, R. R. R.; SOUZA, M. B. C. A. de. Faço o que digo? A relação entre o Projeto Político Pedagógico e a prática Docente. Revista Foco, v.10, n. 2, jan./jul. 2017. http:// www.revistafocoadm.org/index.php/foco/article/view/425/240. Acesso em: 10 fev. 2018.

MASETTO, M. T. Competência pedagógica do professor universitário. São Paulo: Summus, 2012.

MATOS, J. S. Os livros didáticos como produtos para o ensino de História: uma análise do Plano Nacional do Livro Didático - PNLD. Historiæ, Rio Grande, v. 3. n. 3, p. 165-184, set./ dez. 2012. Disponível em: https:// furg.emnuvens.com.br/hist/article/view/3268/1945. Acesso em: 02 jan. 2018.

MINISTÉRIO DA EDUCAÇÃO. FUNDO NACIONAL DE DESENVOLVIMENTO DA EDUCAÇÃO SECRETARIA DE EDUCAÇÃO BÁSICA. Edital de convocação para inscrição no processo de avaliação e seleção de obras didáticas a serem incluídas no Guia de Livros Didáticos para os Anos Finais do Ensino Fundamental - PNLD/2008. Disponível em: http://www.fnde.gov.br/programas/programas-do-livro/ consultas/editais-programas-livro/item/3014-editais-anteriores. Acesso em: 14 nov. 2017.

MINISTÉRIO DA EDUCAÇÃO. FUNDO NACIONAL DE DESENVOLVIMENTO DA EDUCAÇÃO SECRETARIA DE EDUCAÇÃO BÁSICA. Edital de convocação para inscrição no processo de avaliação e seleção de coleções didáticas para o Programa Nacional do Livro Didático - PNLD 2011. Disponível em: http://www.fnde.gov.br/programas/programas-do-livro/ consultas/editais-programas-livro/item/3014-editais-anteriores. Acesso em: 14 nov. 2017.

MINISTÉRIO DA EDUCAÇÃO. FUNDO NACIONAL DE DESENVOLVIMENTO DA EDUCAÇÃO SECRETARIA DE EDUCAÇÃO BÁSICA. Edital de convocação para o processo de inscrição e avaliação de coleções didáticas para o Programa Nacional do Livro Didático - PNLD 2014. p. 65. Disponível em: http://www.fnde.gov. br/programas/programas-do-livro/consultas/editais-programas-livro/item/3014-editaisanteriores. Acesso em: 14 nov. 2017.

MINISTÉRIO DA EDUCAÇÃO. SECRETARIA DE EDUCAÇÃO CONTINUADA, ALFABETIZAÇÃO, DIVERSIDADE E INCLUSÃO. Relatório de gestão do exercício de 2012. Brasília, 2013. Disponível em: http://portal.mec.gov.br/index.php?option=com_ docman $\&$ view $=\% 20$ download $\&$ alias $=14256$-relatorio-gestao-da-secadi-exercicio-2012pdf\&Itemid=30192. Acesso em: 31 jan. 2018.

MINISTÉRIO DA EDUCAÇÃO. SECRETARIA DE EDUCAÇÃO CONTINUADA, ALFABETIZAÇÃO, DIVERSIDADE E INCLUSÃO. Relatório de gestão do exercício de 2013. Brasília, 2014. Disponível em: http://portal.mec.gov.br/index.php?option=com_ docman\&view $=$ download $\&$ alias $=15993$-relatorio-gestao-exercicio-2013-secadipdf\&Itemid=30192. Acesso em: 31 jan. 2018.

MINISTÉRIO DA EDUCAÇÃO. SECRETARIA DE EDUCAÇÃO CONTINUADA, ALFABETIZAÇÃO, DIVERSIDADE E INCLUSÃO. Relatório de gestão do exercício 
de 2015. Brasília, 2016. Disponível em: http://portal.mec.gov.br/index.php?option=com_ docman\&view $=$ download\&alias $=49951-$ rg-se-mec-2015-pdf\&category_slug=outubro2016-pdf\&Itemid=30192. Acesso em: 31 jan. 2018.

MINISTÉRIO DA EDUCAÇÃO. SECRETARIA DE POLÍTICAS DE PROMOÇÃO DA IGUALDADE RACIAL. Prestação de contas ordinária anual e relatório de gestão do exercício de 2011. Brasília, 2012. Disponível em: http://www.seppir.gov.br/sobre-2/ relatorios-de-gestao. Acesso em: 31 jan. 2018.

MINISTÉRIO DA EDUCAÇÃO. SECRETARIA DE POLÍTICAS DE PROMOÇÃO DA IGUALDADE RACIAL. Prestação de contas ordinária anual e relatório de gestão do exercício de 2012. Brasília, 2013. Disponível em: http://www.seppir.gov.br/sobre-2/ relatorios-de-gestao. Acesso em: 31 jan. 2018.

MINISTÉRIO DA EDUCAÇÃO. SECRETARIA DE POLÍTICAS DE PROMOÇÃO DA IGUALDADE RACIAL. Prestação de contas ordinária anual e relatório de gestão do exercício de 2013. Brasília, 2014. Disponível em: http://www.seppir.gov.br/sobre-2/ relatorios-de-gestao. Acesso em: 31 jan. 2018.

MINISTÉRIO DA EDUCAÇÃO. SECRETARIA DE POLÍTICAS DE PROMOÇÃO DA IGUALDADE RACIAL. Prestação de contas ordinária anual e relatório de gestão do exercício de 2014. Brasília, 2015. Disponível em: http://www.seppir.gov.br/sobre-2/ relatorios-de-gestao. Acesso em: 31 jan. 2018.

MINISTÉRIO DA EDUCAÇÃO. SECRETARIA DE POLÍTICAS DE PROMOÇÃO DA IGUALDADE RACIAL. Relatório de gestão do exercício de 2015. Brasília, 2016; idem. Relatório de gestão do exercício de 2016. Brasília, 2017. Disponível em: http:/ /www. seppir.gov.br/sobre-2/relatorios-de-gestao. Acesso em: 31 jan. 2018.

MINISTÉRIO DA EDUCAÇÃO. SECRETARIA DE POLÍTICAS DE PROMOÇÃO DA IGUALDADE RACIAL. Prestação de contas ordinária anual e relatório de gestão do exercício de 2010. Brasília, 2011. Disponível em: http://www.seppir.gov.br/portal-antigo/ relatorios-de-gestao/2010/Relatorio $\% 20$ de $\% 20$ Gestao $\% 202010 \% 20-\% 20$ SEPPIR $\% 20$ -\%20versao\%2031.03.2011.pdf/view. Acesso em: 31 jan. 2018.

NÓVOA, A. Profissão professor. Porto: Porto Editora, 1999.

OLIVEIRA, M. do S. R. de. Ensino de história e identidade negra: importância dos livros didáticos e dos professores na educação de negros. Historiæ, Rio Grande, v. 3, n. 1, p. 7590, jan./abr. 2012. Disponível em: https://www.seer.furg.br/hist/article/view/2481/1803. Acesso em: 02 jan. 2018.

PAULA, B. X. de; GUIMARAES, S. 10 anos da lei federal n 10.639/2003 e a formação de professores: uma leitura de pesquisas científicas. Educação e Pesquisa, São Paulo, v. 40, n. 2, p. 435-448, jun./2014. Disponível em: http://www.scielo.br/pdf/ep/v40n2/v40n2a09. pdf. Acesso em: 14 dez. 2017.

PEREIRA, J. S. Reconhecendo ou construindo uma polaridade étnico-identitária? Desafios do ensino de história no imediato contexto pós-Lei no 10.639. Estudos Históricos (Rio de Janeiro), Rio de Janeiro, v. 21, n. 41, p. 21-43, jun./2008, p. 26-27. Disponível em: http:// www.scielo.br/pdf/eh/v21n41/02.pdf. Acesso em: 14 dez. 2017. 
ROCHA, H. A.; CAIMI, F. E. A(s) história(s) contada(s) no livro didático hoje: entre o nacional e o mundial. Revista Brasileira de História, São Paulo, v. 34, n. 68, p. 125-147, 2014. Disponível em: http://www.scielo.br/pdf/rbh/v34n68/a07v34n68.pdf. Acesso em: 02 jan. 2018.

SANTANA, M. A. Discriminação racial no cotidiano escolar: o que dizem as Diretoras. Revista Fórum Identidade, Itabaiana, n. 6, v. 11, p. 105-119, jan./jun, 2012. Disponível em: https://seer.ufs.br/index.php/forumidentidades/article/view/1829. Acesso em: 10 jan. 2018.

TEXEIRA, E. de O.: VARGAS, H. M. Tensionando os números: o ensino fundamental está mesmo universalizado para crianças e adolescentes negros?. In: $38^{a}$ REUNIÃO NACIONAL DA ANPED. 2017, Maranhão. Anais da 38ª Reunião Nacional da ANPED, 2017. Disponível em: http://www.anped.org.br/biblioteca/item/tensionando-os-numeroso-ensino-fundamental-esta-mesmo-universalizado-para-criancas. Acesso em: 28 dez. 2018.

UNIVERSIDADE FEDERAL DE GOIÁS. Resolução - CEPEC n ${ }^{\circ}$ 1364, de 8 de janeiro de 2015. Disponível em: https://www.ufg.br/n/63397-resolucoes. Acesso em: 29 nov. 2017.

UNIVERSIDADE feDERAL DE RORAIMA. Projeto Político Pedagógico do Curso de Licenciatura em História. 2012. Disponível em: http://ufrr.br/historia/index. php?option $=$ com_phocadownload\&view $=$ category\&id=2\&Itemid=201. Acesso em: 29 nov. 2017.

Universidade federal De SANTA CATARINA. Projeto Político Pedagógico do Curso de Graduação em História (Habilitação única: Bacharelado e Licenciatura em História). 2006. Disponível em: http://historia.grad.ufsc.br/files/2012/03/ppp.pdf. Acesso em: 29 nov. 2017.

UnIVERSIDAde federal DO AMAPÁ. Projeto Político Pedagógico do Curso de História - Licenciatura. 2007. Disponível em: http://www2.unifap.br/historia/ files/2013/04/licenciaturahistoria.pdf. Acesso em: 29 nov. 2017.

UnIVErsidade federal do CEARÁ. Projeto Político Pedagógico do Curso de História - Modalidade Licenciatura. 2005. Disponível em: https://si3.ufc.br/sigaa/public/ curso/ppp.jsf?lc=pt_BR\&id=657460. Acesso em: 29 nov. 2017.

UNIVERSIDADE FEDERAL DO MATRO GROSSO. Projeto Pedagógico do Curso de Graduação em História (Licenciatura). 2009. Disponível em: http:/ /sistemas.ufmt. br/ufmt.ppc/PlanoPedagogico/Download/131. Acesso em: 29 nov. 2017.

UNIVERSIDADE FEDERAL DO PARANÁ. Projeto Pedagógico da Formação Acadêmica e Profissional a ser oferecida aos alunos do curso de Graduação em História. [s.d.]. Disponível em: http://www.historia.ufpr.br/docs/projeto_pedagogico_ diurno.pdf. Acesso em: 29 nov. 2017.

UNIVERSIDADE FEDERAL DO PIAUÍ. Projeto Político-Pedagógico - Curso de Graduação. Licenciatura em História. 2011. Disponível em: http://leg.ufpi.br/ subsiteFiles/cc/arquivos/files/historia_licen_noturno.pdf. Acesso em: 29 nov. 2017.

UNIVERSIDADE FEDERAL DO RIO DE JANEIRO. Manual do Estudante Instituto de História. 2012. Disponível em: http://www.historia.ifcs.ufrj.br/pdfs/ Manual2012.1.pdf. Acesso em: 29 nov. 2017. 
UNIVESIDADE FEDERAL DE MINAS GERAIS. Projeto Pedagógico do Curso de Graduação em História (Licenciatura e Bacharelado). 2009. Disponível em: http://www. fafich.ufmg.br/atendimento/historia/Projeto $\% 20$ Pedagogico $\% 20 \mathrm{do} \% 20 \mathrm{Curso} \% 20 \mathrm{de} \% 20$ Historia.pdf/view. Acesso em: 29 nov. 2017.

VEIGA, I. P. A. Inovações e projeto político-pedagógico: Uma relação regulatória ou emancipatória? Caderno Cedes, Campinas, v. 23, n. 61, p. 267-281, dez. 2003. Disponível em: http://www.scielo.br/pdf/ccedes/v23n61/a02v2361.pdf. Acesso em: 10 jan. 2018.

\section{NOTAS}

${ }^{1}$ BRASIL. Lei $n^{\circ}$ 10.639, de 9 de janeiro de 2003. Altera a lei no 9.394, de 20 de dezembro de 1996, que estabelece as diretrizes e bases da educação nacional, para incluir no currículo oficial da rede de ensino a obrigatoriedade da temática "História e Cultura Afro-brasileira", e dá outras providências. Disponível em: http://www.planalto.gov.br/ccivil_03/leis/2003/ 110.639.htm. Acesso em: 05 nov. 2017.

${ }^{2} J E S U S$, Rodrigo Ednilson. Diversidade étnico-racial no Brasil: os desafios à Lei no 10.639, de 2003. Revista retratos da Escola, Brasília, v. 7, n. 13, p. 399-412, jul./dez. 2013. Disponível em: http://retratosdaescola.emnuvens.com.br/rde/article/viewFile/314/484. Acesso em: 18 dez. 2017.

${ }^{3}$ Destacamos os estudos de ARAÚJO, Jurandir de Almeida; GIUGLIANI, Beatriz. Por uma educação das relações étnico-raciais. \#Tear: Revista de educação, ciência e tecnologia, Rio Grande do Sul, v. 3, n. 1, 2014. Disponível em: https://periodicos.ifrs.edu.br/index.php/ tear/article/view/1833/1431. Acesso em: 14 dez. 2017.

${ }^{4}$ COELHO, Wilma de Nazaré Baía; COELHO, Mauro Cezar. Os conteúdos étnico-raciais na educação brasileira: práticas em curso. Educar em Revista, Curitiba, n. 47, p. 67-84, mar./2013. Disponível em: http://www.scielo.br/pdf/er/n47/06.pdf. Acesso em: 28 nov. 2017.

${ }^{5}$ CANEN, Ana. Currículo para o Desafio à Xenofobia: algumas reflexões multiculturais na educação. Conbecimento \& Diversidade, v.6, n. 11, p. 89-98, 2014. p. 92. Disponível em: https:// revistas.unilasalle.edu.br/index.php/conhecimento_diversidade/article/view/1742. Acesso em: 13 jan. 2018.

${ }^{6}$ MINISTÉRIO DA EDUCAÇÃO. FUNDO NACIONAL DE DESENVOLVIMENTO DA EDUCAÇÃO SECRETARIA DE EDUCAÇÃO BÁSICA. Edital de convocação para inscrição no processo de avaliação e seleção de obras didáticas a serem incluidas no Guia de Livros Didáticos para os Anos Finais do Ensino Fundamental - PNLD/2008. p. 4.; idem. Edital de convocação para inscrição no processo de avaliação e seleção de coleções didáticas para o Programa Nacional do Livro Didático - PNLD 2011. p. 46; idem. Edital de convocação para o processo de inscrição e avaliação de coleções didáticas para o Programa Nacional do Livro Didático - PNLD 2014. p. 65. Todos disponíveis em: http://www.fnde.gov.br/programas/programas-do-livro/consultas/editais-programaslivro/item/3014-editais-anteriores. Acesso em: 14 nov. 2017.

${ }^{7}$ Entre as discussões relevantes acerca do assunto, mencionamos os trabalhos de OLIVEIRA, Maria do Socorro Ramos de. Ensino de história e identidade negra: importância dos livros didáticos e dos professores na educação de negros. Historia, Rio Grande, v. 3, n. 1, p. 75 - 
90, jan./abr. 2012. Disponível em: https://www.seer.furg.br/hist/article/view/2481/1803. Acesso em: 02 jan. 2018; MATOS, Júlia Silveira. Os livros didáticos como produtos para o ensino de História: uma análise do Plano Nacional do Livro Didático - PNLD. Historia, Rio Grande, v. 3. n. 3, p. 165-184, set./dez. 2012. Disponível em: https://furg.emnuvens.com.br/ hist/article/view/3268/1945. Acesso em: 02 jan. 2018; DEBONA, Jackson James; RIBEIRO, Renilson Rosa. Relações de gênero e livro didático de história: uma abordagem possível? Revista Educacão e Fronteiras On-Line, Dourados/MS, v.4, n.11, p. 126-143, mai./ago. 2014. Disponível em: http://ojs.ufgd.edu.br/index.php/educacao/article/view/4368/pdf_238. Acesso em: 02 jan. 2018; ROCHA, Helenice Aparecida; CAIMI, Flávia Eloisa. A(s) história(s) contada(s) no livro didático hoje: entre o nacional e o mundial. Revista Brasileira de História, São Paulo, v. 34, n. 68, p. 125-147, 2014. Disponível em: http://www.scielo.br/pdf/rbh/v34n68/a07v34n68. pdf. Acesso em: 02 jan. 2018; CAIMI, Flávia Eloisa; OLIVEIRA, Sandra Regina Ferreira de. Progressão do conhecimento histórico entre o ensino fundamental e o ensino médio: um olhar sobre o livro didático. Acta Scientiarum, Maringá, v. 39, p. 483-495, 2017. Disponível em: http://periodicos.uem.br/ojs/index.php/ActaSciEduc/article/view/29864/21106. Acesso em 02 jan. 2018; GERMINARI, Geyso D.; MOURA, Anderson Fagundes de. Livro didático de história, entre conteúdos e epistemologia. Educação Unisinos, Rio Grande do Sul, v. 21, n. 1, p. 102-110, jan./abr. 2017. Disponível em: http://revistas.unisinos.br/index.php/educacao/ article/view/edu.2017.211.11/5858. Acesso em: 02 jan. 2018.

${ }^{8}$ COELHO, Mauro Cezar; COELHO, Wilma de Nazaré Baía. "Jogando verde e colhendo maduro": historiografia e saber histórico escolar no ensino de História da África e da Cultura Afro-Brasileira. Territórios e Fronteiras, Cuiabá, v. 6, n. 3, p. 92-107, 2013. Disponível em: http://www.ppghis.com/territorios\&fronteiras/index.php/v03n02/article/view/247/180. Acesso em: 02 jan. 2018; idem; idem. A diversidade na história ensinada nos livros didáticos: mudanças e permanências nas narrativas sobre a formação da nação. História e Diversidade, Cáceres, v. 6, n. 1, p. 6-21, 2015. Disponível em: https://periodicos.unemat.br/index.php/ historiaediversidade/article/view/866/855. Acesso em: 02 jan. 2018.

${ }^{9}$ Ver trabalhos de BICALHO, Poliene Soares dos Santos. As assembleias indígenas o advento do movimento indígena no Brasil. Opsis, Catalão, v. 10, n. 1, p. 91-114, jan./ jun. 2010. Disponível em: https://revistas.ufg.br/Opsis/article/view/9553/8474\#. Wn4GhGnwbIU. Acesso em: 14 dez. 2017; GONÇALVES, Luis Alberto; SILVA, Petronilha Beatriz Gonçalves e. Movimento negro e educação. Revista Brasileira de Educação, Rio de Janeiro, n. 15, p. 134-158, set./dez. 2000. Disponível em http://www.scielo.br/scielo. php?pid=S1413-24782000000300009\&script=sci_abstract\&tlng=pt. Acesso em 10 jan. 2018; FREITAS, Marcos Antonio Braga; TORRE, Iraildes Caldas. O papel do movimento indígena no processo de escolarização do ensino Superior na Amazônia. Olhares Amazônicos, Boa Vista, v. 4, n. 1, p. 748-761, jan./jun. 2016. Disponível em: https://ufrr.br/roa/index. php/21-volume-4-numero-1. Acesso em: 02 dez. 2017; GOMES, Nilma Lino Gomes. O Movimento Negro educador: saberes construídos nas lutas por emancipação. Petrópolis: Vozes, 2017; FERNANDES, Fernando Roque; COELHO, Mauro Cezar Coelho. "Ame-o ou emancipe-o": contradições da emancipação nos discursos, práticas e representações dos/ sobre os povos indígenas no Brasil (1970/1980) In: COELHO, Wilma de Nazaré Baía; COELHO, Mauro Cezar (org.) Debates Interdisciplinares sobre Educação e Diversidade. São Paulo: Ed. Livraria da Física, 2018. p.15-48.

${ }^{10}$ CONSELHO NACIONAL DE EDUCAÇÃO. Resolução CNE/CP 1/2004. Institui Diretrizes Curriculares Nacionais para a Educação das Relações Étnico-Raciais e para o Ensino de História e Cultura Afro-Brasileira e Africana. Disponível em http://portal.mec. 
gov.br/cne/arquivos/pdf/res012004.pdf. Acesso em: 11 abr. 2013; idem. Parecer CNE/CP 3/2004. Diretrizes Curriculares Nacionais para a Educação das Relações Étnico-Raciais e para o Ensino de História e Cultura Afro-Brasileira e Africana. Disponível em http://portal. mec.gov.br/cne/arquivos/pdf/003.pdf. Acessado em: 11 abr. 2013.

${ }^{11}$ DA MATTA, Roberto. Digressão: A Fábulas das Três Raças ou o Problema do Racismo à Brasileira. In: Relativizando: uma introdução à Antropologia Social. Petrópolis: Vozes, 1981, p. $58-85$.

${ }^{12}$ CONSELHO NACIONAL DE EDUCAÇÃO. Resolução CNE/CP 1/2004. Op. cit.; idem. Parecer CNE/CP 3/2004. Op. cit.

${ }^{13}$ COELHO, Wilma de Nazaré Baía; COELHO, Mauro Cezar (org.). Raça, Cor e Diferença: a escola e a diversidade. Belo Horizonte: Mazza, 2008; idem; idem. Entre Virtudes e Vicios: educação, sociabilidades, cor e ensino de História. São Paulo: Editora Livraria da Física, 2014.

${ }^{14}$ Ver algumas das ações nos seguintes documentos: MINISTÉRIO DA EDUCAÇÃO. SECRETARIA DE POLÍTICAS DE PROMOÇÃO DA IGUALDADE RACIAL. Prestação de contas ordinária anual e relatório de gestão do exercício de 2011. Brasília, 2012; idem. Prestação de contas ordinária anual e relatório de gestão do exercício de 2012. Brasília, 2013; idem. Prestação de contas ordinária anual e relatório de gestão do exercício de 2013. Brasília, 2014; idem. Prestação de contas ordinária anual e relatório de gestão do exercício de 2014. Brasília, 2015; idem. Relatório de gestão do exercício de 2015. Brasília, 2016; idem. Relatório de gestão do exercício de 2016. Brasília, 2017. Todos disponíveis em: http://www.seppir.gov.br/sobre-2/relatorios-de-gestao. Acesso em: 31 jan. 2018.

${ }^{15} \mathrm{~A}$ origem do termo licenciatura decorre do fato de que o estado concedia uma licença para aqueles nos quais era reconhecida uma competência específica para o ensino: o domínio de saberes a serem ensinados. Sobre esse tema ver NÓVOA, Antônio. Profissão professor. Porto: Porto Editora, 1999, p.17.

${ }^{16}$ CONSELHO NACIONAL DE EDUCAÇÃO. Parecer CNE/CP 2/2015. Diretrizes Curriculares Nacionais para a Formação Inicial e Continuada dos Profissionais do Magistério da Educação Básica. Disponível em: http://portal.mec.gov.br/index.php?option=com_ docman\&view $=$ download\&alias $=17625$-parecer-cne-cp-2-2015-aprovado- 9 -junho2015\&category_slug=junho-2015-pdf\&Itemid=30192. Acessado em: 28/11/2017; idem. Resolução CNE/CP 2/2015. Define as diretrizes Curriculares Nacionais para a formação inicial em nível superior (cursos de licenciatura, cursos de formação pedagógica para graduados e cursos de segunda licenciatura) e para a formação continuada. Disponível em: http://portal. mec.gov.br/index.php?option $=$ com_docman\&view $=$ download\&alias $=70431$-res-cne-cp-00203072015-pdf\&category_slug=agosto-2017-pdf\&Itemid=30192. Acesso em: 28 nov. 2017.

${ }^{17}$ Sobre os valores que devem pautar a Educação, ver BRASIL. Constituição da República Federativa do Brasil de 1988. [Artigo 206]. Disponível em: http://www.planalto.gov.br/ ccivil_03/constituicao/constituicaocompilado.htm. Acessado em: 28/01/2018; BRASIL. Lei $n^{\circ}$ 9.394, de 09 de janeiro de 1996. Estabelece as Diretrizes e Bases da Educação Nacional. [Artigo 27]. Disponível em: https://www.planalto.gov.br/ccivil_03/Leis/L9394.htm. Acesso em: 28 jan. 2018.

${ }^{18}$ UNIVERSIDAde FEDERAL DO AMAPÁ. Projeto Político Pedagógico do Curso de História - Licenciatura. 2007. Disponível em: http://www2.unifap.br/historia/ files/2013/04/licenciaturahistoria.pdf. Acesso em: 29 nov. 2017. 
${ }^{19}$ UNIVERSIDAde federal Do CEARÁ. Projeto Político Pedagógico do Curso de História - Modalidade Licenciatura. 2005. Disponível em: https://si3.ufc.br/sigaa/public/ curso/ppp.jsf?lc=pt_BR\&id=657460. Acesso em: 29 nov. 2017.

${ }^{20}$ UNIVERSIDADE FEDERAL DE GOIÁS. Resolução - CEPEC nº 1364, de 8 de janeiro de 2015. Disponível em: https://www.ufg.br/n/63397-resolucoes. Acesso em: 29 nov. 2017.

${ }^{21}$ UNIVERSIDADE FEDERAL DO MATRO GROSSO. Projeto Pedagógico do Curso de Graduação em História (Licenciatura). 2009. Disponível em: http://sistemas.ufmt.br/ufmt. ppc/PlanoPedagogico/Download/131. Acesso em: 29 nov. 2017.

${ }^{22}$ UNIVESIDADE FEDERAL DE MINAS GERAIS. Projeto Pedagógico do Curso de Graduação em História (Licenciatura e Bacharelado). 2009. Disponível em: http://www. fafich.ufmg.br/atendimento/historia/Projeto $\% 20$ Pedagogico $\% 20 \mathrm{do} \% 20 \mathrm{Curso} \% 20 \mathrm{de} \% 20$ Historia.pdf/view. Acesso em: 29 nov. 2017.

${ }^{23}$ UNIVERSIDADE FEDERAL DO PARANÁ. Projeto Pedagógico da Formação Acadêmica e Profissional a ser oferecida aos alunos do curso de Graduação em História. [s.d.]. Disponível em: http://www.historia.ufpr.br/docs/projeto_pedagogico_diurno.pdf. Acesso em: 29 nov. 2017.

${ }^{24}$ UNIVERSIDADE FEDERAL DO PIAUÍ. Projeto Político-Pedagógico - Curso de Graduação. Licenciatura em História. 2011. Disponível em: http://leg.ufpi.br/subsiteFiles/ cc/arquivos/files/historia_licen_noturno.pdf. Acesso em: 29 nov. 2017.

${ }^{25}$ UNIVERSIDADE FEDERAL DO RIO DE JANEIRO. Manual do Estudante - Instituto de História. 2012. Disponível em: http://www.historia.ifcs.ufrj.br/pdfs/Manual2012.1.pdf. Acesso em: 29 nov. 2017.

${ }^{26}$ UNIVERSIDADE fEDERAL DE RORAIMA. Projeto Político Pedagógico do Curso de Licenciatura em História. 2012. Disponível em: http://ufrr.br/historia/index.php?option=com_ phocadownload\&view $=$ category\&id $=2 \& I t e m i d=201$. Acesso em: 29 nov. 2017.

${ }^{27}$ UNIVERSIDADE FEDERAL DE SANTA CATARINA. Projeto Político Pedagógico do Curso de Graduação em História (Habilitação única: Bacharelado e Licenciatura em História). 2006. Disponível em: http://historia.grad.ufsc.br/files/2012/03/ppp.pdf. Acesso em: 29 nov. 2017.

${ }^{28}$ Fonte: Elaborado pelos autores a partir dos Projetos Político-Pedagógicos dos cursos das respectivas instituições, fev.2018

${ }^{29}$ A perspectiva de Ilma Passos Alencastro Veiga (2003) foi a escolhida para o tratamento dos dados obtidos neste estudo por apresentar questões relevantes sobre Projetos PolíticoPedagógicos. Para a autora, tais documentos indicam o modo pelo qual a formação é concebida e sua oferta é projetada. VEIGA, Ilma Passos Alencastro. Inovações e projeto políticopedagógico: Uma relação regulatória ou emancipatória? Caderno Cedes, Campinas, v. 23, n. 61, p. 267-281, dez. 2003. Disponível em: http://www.scielo.br/pdf/ccedes/v23n61/a02v2361. pdf. Acesso em: 10 jan. 2018. Para o autor Marcos Tarcísio Masseto, o currículo dos cursos de graduação representam um conjunto de disciplinas que transmitem os conhecimentos necessários para a formação de um profissional, por meio de disciplinas justapostas. MASETTO, Marcos Tarcísio. Competência pedagógica do professor universitário. São Paulo: Summus, 2012. Os 
autores Ricardo Ribeiro Rocha Marques e Marina Batista Chaves Azevedo de Souza afirmam, a partir de estudos recentes, que há necessidade de um melhor relação entre o que está previsto no Projeto Político-Pedagógico/Projeto Pedagógico de Curso, o engajamento docente com as questões previstas no mesmo projeto e a integração das atividades dos docentes formadores com o que aquele projeto prevê. MARQUES, Ricardo Ribeiro Rocha; SOUZA, Marina Batista Chaves Azevedo de. Faço o que digo? A relação entre o Projeto Político Pedagógico e a prática Docente. Revista Foco, v.10, n. 2, jan./jul. 2017. http://www.revistafocoadm.org/index.php/ foco/article/view/425/240. Acesso em: 10 fev. 2018.

${ }^{30}$ BARDIN, Laurence. Análise do conteúdo. Lisboa: Edições 70, 2011.

${ }^{31}$ Trata-se do Projeto Político Pedagógico do Curso de História da Universidade Federal do Rio de Janeiro.

${ }^{32}$ UNIVERSIDADE FEDERAL DO AMAPÁ. Op. cit., p. 10.

${ }^{33}$ UNIVERSIDADE FEDERAL DO PARANÁ. Op. cit., p. 5.

${ }^{34}$ UNIVERSIDADE FEDERAL DO CEARÁ. Op. cit., p. 9; UNIVERSIDADE FEDERAL DO MATO GROSSO. Op. cit., p. 13, UNIVERSIDADE FEDERAL DE RORAIMA. Op. cit., p. 7.

${ }^{35}$ UNIVERSIDADE FEDERAL DE GOIÁS. Op. cit., p. 16.

${ }^{36}$ UNIVERSIDADE FEDERAL DE SANTA CATARINA. Op. cit., p. 32.

${ }^{37}$ UNIVERSIDADE FEDERAL DO PIAUÍ. Op. cit., p. 21.

${ }^{38}$ CONSELHO NACIONAL DE EDUCAÇÃO. Parecer CEN/CES 492/2001. Diretrizes Curriculares Nacionais dos cursos de Filosofia, História, Geografia, Serviço Social, Comunicação Social, Ciências Sociais, Letras, Biblioteconomia, Arquivologia e Museologia. Disponível em: http://portal.mec.gov.br/cne/arquivos/pdf/CES0492.pdf. Acesso em: 04/12/2017; idem. Resolução CNE/CES 13/2002. Estabelece as Diretrizes Curriculares para os cursos de História. Disponível em: http://portal.mec.gov.br/cne/arquivos/pdf/ CES132002.pdf. Acesso: em 04/12/2017.

${ }^{39}$ UNIVERSIDADE FEDERAL DO CEARÁ. Op. cit., p. 9; UNIVERSIDADE FEDERAL DE GOIÁS. Op. cit., p. 42; UNIVERSIDADE FEDERAL DO MATO GROSSO. Op. cit., p. s.i.; UNIVERSIDADE FEDERAL DO PIAUÍ. Op. cit., p. 91; UNIVERSIDADE FEDERAL DO RIO DE JANEIRO. Op. cit., p. 6 e UNIVERSIDADE FEDERAL DE SANTA CATARINA. Op. cit., p. 3, 21, 32, 37, 41, 45, 48, 51.

${ }^{40}$ CONSELHO NACIONAL DE EDUCAÇÃO. Parecer CEN/CES 492/2001. Op. cit., p. 8-9.

${ }^{41}$ MINISTÉRIO DA EDUCAÇÃO. SECRETARIA DE POLÍTICAS DE PROMOÇÃO DA IGUALDADE RACIAL. Prestação de contas ordinária anual e relatório de gestão do exercício de 2010. Brasília, 2011. Disponível em: http://www.seppir.gov.br/portal-antigo/relatorios-degestao/2010/Relatorio $\% 20$ de $\% 20$ Gestao $\% 202010 \% 20-\% 20$ SEPPIR $\% 20-\% 20$ versao $\% 20$ 31.03.2011.pdf/view. Acesso em: 31/01/2018; MINISTÉRIO DA EDUCAÇÃO. SECRETARIADEEDUCAÇÃO CONTINUADA, ALFABETIZAÇÃO,DIVERSIDADE E INCLUSÃO. Relatório de gestão do exercício de 2012. Brasília, 2013. Disponível em: http:// portal.mec.gov.br $/$ index.php?option $=$ com_docman\&view $=\% 20$ download $\&$ alias $=14256-$ 
relatorio-gestao-da-secadi-exercicio-2012-pdf\&Itemid=30192. Acesso em: 31 jan. 2018; idem. Relatório de gestão do exercício de 2013. Brasília, 2014. Disponível em: http://portal. mec.gov.br $/$ index.php?option $=$ com_docman $\&$ view $=$ download $\&$ alias $=15993$-relatoriogestao-exercicio-2013-secadi-pdf\&Itemid=30192. Acesso em: 31/01/2018; idem. Relatório de gestão do exercício de 2015. Brasília, 2016. Disponível em: http://portal.mec.gov.br/index. php?option $=$ com_docman\&view $=$ download\&alias $=49951-$ rg-se-mec-2015-pdf\&category_ slug=outubro-2016-pdf\&Itemid=30192. Acesso em: 31 jan. 2018.

${ }^{42}$ PAULA, Benjamin Xavier de; GUIMARAES, Selva. 10 anos da lei federal no 10.639/2003 e a formação de professores: uma leitura de pesquisas científicas. Educação e Pesquisa, São Paulo, v. 40, n. 2, p. 435-448, jun./2014. Disponível em: http://www.scielo.br/pdf/ep/ v40n2/v40n2a09.pdf. Acesso em: 14 dez. 2017.

${ }^{43}$ FERNANDES, José Ricardo Oriá. Ensino de história e diversidade cultural: desafios e possibilidades. Cadernos CEDES, Campinas, v. 25, n. 67, p. 378-388, dez./2005. Disponível em: http://www.scielo.br/pdf/ccedes/v25n67/a09v2567.pdf. Acesso em: 14 dez. 2017.

${ }^{44}$ PEREIRA, Júnia Sales. Reconhecendo ou construindo uma polaridade étnico-identitária? Desafios do ensino de história no imediato contexto pós-Lei no 10.639. Estudos Históricos (Rio de Janeiro), Rio de Janeiro, v. 21, n. 41, p. 21-43, jun./2008, p. 26-27. Disponível em: http:// www.scielo.br/pdf/eh/v21n41/02.pdf. Acesso em: 14 dez. 2017.

${ }^{45}$ idem, p. 29-31. As críticas às Diretrizes Curriculares Nacionais demandam uma reflexão específica, de modo que não nos ocuparemos delas neste texto.

${ }^{46}$ idem, p. 24.

${ }^{47}$ idem, p. 28-29.

${ }^{48}$ Segundo o Conselho Nacional de Educação a carga horária relativa à Prática como Componente Curricular pode ser ofertada como parte de disciplinas voltadas para a formação pedagógica, mas não aquelas relativas aos fundamentos técnico-científicos de uma dada área do conhecimento. Assim, a carga horária de quatrocentas horas de Prática como Componente Curricular não deve compor a carga horária de disciplinas relativas ao saber de referência. Ver sobre isso CONSELHO NACIONAL DE EDUCAÇÃO. Parecer CNE/CES 15/2005, p 3. Disponível em http://portal.mec.gov.br/cne/arquivos/pdf/ pces0015_05.pdf. Acesso em 20 nov. 2017.

${ }^{49}$ CONSELHO NACIONAL DE EDUCAÇÃO. Resolução CNE/CP 2/2002. Institui a duração e a carga horária dos cursos de licenciatura, de graduação plena, de formação de professores da Educação Básica em nível superior. Disponível em: http://portal.mec.gov. br/cne/arquivos/pdf/CP022002.pdf. Acesso em: 28 dez. 2017.

${ }^{50}$ Citamos, aqui, dois estudos muito citados acerca do tema: CAIMI, Flávia Eloisa. Por que os alunos (não) aprendem História? Reflexões sobre ensino, aprendizagem e formação de professores de História. Tempo, Niterói, v. 11, n. 21, 17-32, 2006. Disponível em: http:// www.scielo.br/pdf/tem/v11n21/v11n21a03.pdf. Acesso em: 19 dez. 2017; FERREIRA, Marieta de Moraes; FRANCO, Renato. Desafios do ensino de história. Estudos Históricos, Rio de Janeiro, vol. 21, no 41, 79-93, jan.-jun./2008. Disponível em: http://www.scielo.br/pdf/ eh/v21n41/05.pdf. Acessado em: 19 dez. 2017. 
${ }^{51}$ UNIVERSIDADE FEDERAL DE MINAS GERAIS. Op. cit., p. 26.

${ }^{52}$ UNIVERSIDADE FEDERAL DE SANTA CATARINA. Op. cit., p. 23.

${ }^{53}$ UNIVERSIDADE FEDERAL DO PIAUÍ. Op. cit., 47.

${ }^{54}$ UNIVERSIDADE FEDERAL DE SANTA CATARINA. Op. cit., p. 72.

${ }^{55}$ CUNHA, Manuela Carneiro da. Introdução a uma história indígena. In: CUNHA, Manuela Carneiro da (org.). História dos Índios no Brasil. São Paulo: Companhia das Letras; Secretaria Municipal de Cultura; FAPESP, 1992. p. 9-24.

${ }^{56}$ CONSELHO NACIONAL DE EDUCAÇÃO. Resolução CNE/CP 1/2002. Institui Diretrizes Curriculares Nacionais para a Formação de Professores da Educação Básica, em nível superior, curso de licenciatura, de graduação plena, Art. $6^{\circ}$. Disponível em: http:// portal.mec.gov.br/cne/arquivos/pdf/rcp01_02.pdf. Acesso em: 04 dez. 2017.

${ }^{57}$ CONSELHO NACIONAL DE EDUCAÇÃO. Parecer CNE/CP 9/2001. Diretrizes Curriculares Nacionais para a Formação de Professores da Educação Básica, em nível superior, curso de licenciatura, de graduação plena, p. 42 e 46. Disponível em: http:/ / portal. mec.gov.br/cne/arquivos/pdf/009.pdf. Acesso em: 06 dez. 2017.

${ }^{58}$ CONSELHO NACIONAL DE EDUCAÇÃO. Parecer CNE/CP 3/2004. Op. cit., p. 2, $8,13,14-16$.

${ }^{59}$ FURET, François. A oficina da História. Gradiva: Lisboa, s.d., p. 7-37.

${ }^{60}$ FORMARI, Liamara Teresinha. Reflexões acerca da reprovação e evasão escolar e os determinantes do capital. Revista Espaço Pedagógico, Passo Fundo, v. 17, n. 1, p. 112-124, jan./ jun. 2010. Disponível em: http://seer.upf.br/index.php/rep/article/view/2027. Acesso em: 28/01/2018; BORJA, Izabel Maria França de Souza; MARTINS, Alcina Manuela de Oliveira. Evasão escolar: desigualdade e exclusão social. Revista Liberato, Novo Hamburgo, v. 15, n. 23, p. 01-104, jan./jun. 2014. Disponível em: http://www.liberato.com.br/sites/ default/files/arquivos/liberato_informa/liberato_informa_02_de_julho.pmd_.pdf. Acesso em: 30 dez. 2018; TEXEIRA, Eliana de Oliveira: VARGAS, Hustana Maria. Tensionando os números: o ensino fundamental está mesmo universalizado para crianças e adolescentes negros?. In: $38^{a}$ REUNIÃO NACIONAL DA ANPED. 2017, Maranhão. Anais da $38^{a}$ Reunião Nacional da ANPED, 2017. Disponível em: http://www.anped.org.br/biblioteca/ item/tensionando-os-numeros-o-ensino-fundamental-esta-mesmo-universalizado-paracriancas. Acesso em: 28 dez. 2018.

${ }^{61}$ CORDEIRO, Aliciene Fusca Machado; BUENDGENS, Jully Fortunato. Preconceitos na escola: sentidos e significados atribuídos pelos adolescentes no ensino médio Cordeiro. Revista Semestral da Associação Brasileira de Psicologia Escolar e Educacional, São Paulo, v. 16, n. 1, p. 45-54, jan./jun. 2012. Disponível em: https://abrapee.files.wordpress.com/2012/02/ abrapee_v16n1-1.pdf. Acesso em: 10 jan. 2018; SANTANA, Malsete Arestides. Discriminação racial no cotidiano escolar: o que dizem as Diretoras. Revista Fórum Identidade, Itabaiana, n. 6, v. 11, p. 105-119, jan./jun, 2012. Disponível em: https://seer.ufs.br/index. php/forumidentidades/article/view/1829. Acesso em: 10 jan. 2018; COELHO, Mauro Cezar. História Indígena - provocações para os historiadores. História Viva (São Paulo), v. XI, p. 24-27, 2014; COELHO, Wilma de Nazaré Baía; COELHO, Mauro Cezar. Preconceito 
e discriminação para além das salas de aula: sociabilidades e cultura juvenil no ambiente escolar? Revista Instituto de Estudos Brasileiros, São Paulo, v. 62, p. 1-22, 2015. Disponível em: https://www.revistas.usp.br/rieb/article/view/107185. Acesso em: 10 jan. 2018.

${ }^{62}$ O Projeto Político-Pedagógico da UFSC faz o mesmo, considerando a Arte Americana e Indígena.

${ }^{63}$ Conforme aponta o gráfico II.

${ }^{64}$ Sobre isto ver GOMES, Nilma Lino (org.). Práticas pedagógicas de trabalho com relações étnicoraciais na escola na perspectiva da Lei n. 10.639/2003. Brasília: MEC/UNESCO, 2012.

${ }^{65}$ PEREIRA, Júnia Sales. Op. cit., p. 29-31.

${ }^{66}$ Conforme a tabela III - nela verifica-se que, em média, a carga horária relativa à formação docente ocupa 16,61\%.

Submetido: $15 / 03 / 2018$

Aprovado: 26/04/2018

Contato:

Mauro Cezar Coelho

Avenida Gentil Bitencourt, 544/205 - Nazaré

Belém |PA|Brasil

CEP 66.035-340 